\title{
PANDEMİK TEHDİT KARŞISINDA SAĞLIK HAKKININ SOSYO-LEGAL DİNAMİĞİ
}

\author{
Prof. Dr. Muharrem KILIÇ*
}

\begin{abstract}
ÖZET
Dünyada milyonlarca insanı tesiri altına alan Covid-19 pandemisi küresel bir tehlikeye dönüşerek hem bireysel hem de sosyal yaşamın tüm alanlarında köklü düşünsel dönüşümleri icbar eden yeni bir durum yaratmıștır. Küreselleşen modern dünyanın bütün sosyo-ekonomik ve sosyo-politik dinamiklerinde dönüşüme yol açan bu 'kriz hali', kurumsal düzeyde hukuki, siyasi ve iktisadi yapısal kırılmalara zemin hazırlamış, bu kriz ile mücadele kapasitesi olarak 'yeni bir kamusal aklın’ icadı noktasında derin bir düşünümselliğe kapı aralamıştır. Pandemi riskinin kendinde icbâriliği ile tevessül edilen 'istisnâi yönetim' usulleri ve bunun post-pandemik dönem için yönetsel rutine dönüşme olasılığı, bu gündemi kamusal entelektüelliğin tartışma zeminine taşımaktadır.

Bu çalışmaya konu edindiğimiz, sosyal haklar kapsamında tasnif edilen sağlık hakkı, tüm yönleriyle pandemi ile mücadelenin merkezi unsurunu teşkil ettiğinden, ufukta beliren düşünümselliğin önemli bir konusunu oluşturmaktadır. Bu bağlamsal çerçevede burada, modern insan hakları öğretisi ve uygulamasına egemen olan birinci kuşak haklar kataloğunun muhkem çerçevesinin dışında varlık mücadelesini sürdüren ikinci kuşak haklar olarak tanımlanan 'ekonomik, sosyal ve kültürel haklar' kapsamında yer alan sağlık hakkını sosyo-legal dinamiği açısından konu edilecektir.

Anahtar Kelimeler: Covid-19, Pandemi, İnsan Hakları, Sosyal Devlet, Sosyal Haklar, Sağlık Hakkı, Sosyo-legal.

Ankara Yıldırım Beyazıt Üniversitesi Hukuk Fakültesi, Hukuk Felsefesi ve Sosyolojisi Anabilim Dalı, muharremkilic@ybu.edu.tr, ORCID ID: 0000-0002-7937-3998, (Geliş Tarihi: 31.05.2020 - Kabul Tarihi: 30.06.2020).
\end{abstract}




\title{
SOCIO-LEGAL DYNAMICS OF RIGHT TO HEALTH AGAINST THE PANDEMIC THREAT
}

\begin{abstract}
The Covid-19 pandemic, which has influenced millions of people around the world, has turned into a global hazard, creating a new situation that permits radical intellectual transformations in all areas of both individual and social life. This 'state of crisis', which has led to transformation in all socio-economic and socio-political dynamics of the globalizing modern world, has paved the way for legal, political and economic structural breaks at the institutional level and as a capacity to combat this crisis, it opened the door to a deep reflection on the invention of 'a new public reason'. The exceptional measures and its possibility to turn into an administrative routine for the post-pandemic period bring this agenda to the discussion ground for public intellectuality.

Since the right to health, which is classified within the scope of social rights, constitute the central element of the fight against the pandemic in all its aspects, constitutes an important topic of the reflective thinking on the horizon. In this context, the right to health within the scope of 'economic, social and cultural rights', defined as the second generation rights that continue to struggle for existence outside the strong framework of the first generation rights catalog that dominates modern human rights teaching and practice, will be discussed in terms of socio-legal dynamics.
\end{abstract}

Keywords: Covid-19, Pandemic, Human Rights, Social State, Social Rights, Right to Health, Socio-legal. 


\section{Gíriş}

Dünya Sağlık Örgütü 11 Mart 2020 tarihinden itibaren koronavirüse bağlı Covid-19 hastalığını pandemi olarak ilan etmiştir. Dünyada yaklaşık on bir milyonun üzerinde insana bulaşan ${ }^{1}$ bu virüsün enfekte etme düzeyinin yüksekliği, oldukça kısa bir sürede hastalığın küresel ölçekli bir 'kamu sağlığı sorunu' yaratmasına yol açmıştır. Global bir riske dönüşen virüsün yayılım hızı, bütün dünyada hem bireysel hem de sosyal yaşamın tüm alanlarında köklü düşünsel dönüşümleri ve davranışsal tutumları icbar eden yeni bir durum yaratmıştır. Küreselleşen modern dünyanın bütün sosyo-ekonomik ve sosyo-politik dinamiklerinde dönüşüme yol açan bu 'kriz hali', kurumsal düzeyde hukuki, siyasi ve iktisadi yapısal kırılmalara zemin hazırlamıştır. Modern zamanların yalnızca bireysel ve toplumsal düzeyde rutinleșen eylemsellikleri açısından değil, makro ölçekte siyasi ve ekonomik düzenin dinamikleri açısından da bir tür 'istisnaî hâl' veya 'olağanüstülük durumu' ortaya çıkmıştır. İçinde bulunduğumuz tarihsel âna tekaddüm eden ve 'normal' olarak nitelenen hâl ile istikbâle egemen olacak olan durum arasındaki olası 'fark dinamiklerine' ilişkin belirsizlikler derin sosyal/kamusal kaygı bozukluklarına yol açmaktadır. Bir diğer kaygı bozukluğu yaratan faktör, küreselleşen risk karşısında devreye sokulan olağanüstülükler düzeninin pandemi sonrasında olağanlaştırılmış bir sosyo-politik dizgeye ve kamusal yaşam düzenine tahavvül etmesidir. Bütün bu kaygı temelli projektif tasavvurları bir kenara birakarak ifade edecek olursak, pandemi döneminin başka birçok alanda olduğu üzere, bir bütün olarak yerleşik zihin yapılarını ve kamusal aklı yapıbozumuna uğratan bir anafor yarattı̆̆ı aşikârdır.

'Normal-dışı' olarak nitelenen bu yeni durumun, insanlık tarihinde yaşanan pandemi krizlerinin yol açtığı büyük buhranlardan ayrılan birtakım yönlerine dikkat çekebiliriz. Tarihteki yıkıcı pandemilerden farklı olarak laboratuvarda üretilme olasılı̆̆ı üzerine konuşulan Covid-19 pandemisinin, her şeyden önce menşei itibariyle tarihsel örneklerinden ayrışma ihtimalini

1 Dünya Sağlık Örgütü 06 Temmuz 2020 tarihli verilerine göre Dünya genelinde 11.327.790 onaylanmış Covid-19 vakası bulunmaktadır. Onaylanmış ölüm sayısı ise 532.340 olarak kaydedilmiştir. https://www.who.int/emergencies/diseases/novel-coronavirus-2019, s.e.t. 06.07.2020. 
kaydedebiliriz. Menşei konusundaki kuşkuların derin bir tahkikata ihtiyaç duyduğu aşikâr olan koronavirüs, teknolojik modernizasyonun yıkıcı gelişiminin bir eseri olarak değerlendirilebilir. İnsanlık, bu virüsün laboratuvar ortamında üretilme olasılığını bertaraf eden güçlü kanıtlara erişse bile, bu neticeyi mümkün kılma potansiyeline sahip olan 'teknolojik aklın' yıkıcı iktidarının ürküten tablosu ile karşı karşıya olduğumuz bir gerçektir. Bir diğer ayrışan yön ise, küreselleşme ile birlikte dünyanın bütün yaşamsal alanları itibariyle totalleşen sektörlerinin birbirleri ile olan sıkı organik bağıdır. Artık dünya, ünlü 'köy' metaforunun da ötesinde, kaynaşı düzen içerisinde istiflenmiş bir yaşamsallığa mahkûm olmuştur. Devletleri, ulusal sınırları, kısıtlamaları ve engelleri kolaylıkla aşabilen bir 'sosyo-ekonomik iç içe olma hali’ söz konusudur. Yekpare bir üst-kamusal ağ ile örülü ulusların sanal bile olsa maruz kaldıkları yoğun etkileşimi, tam olarak 'yarar' temelinde olmasa da 'zarar' temelinde bir 'küresel eşitlik' düzenine yol açmıştır. Lokomotif sektörel alanlar başta olmak üzere herhangi bir ulusun 'ihmali, ihlali veya kötü yönetimi’, bir bütün olarak küreyi riske maruz bırakabilmektedir. Yine bir başka ayrışan yön ise, bilişim teknolojisi alanındaki dramatik gelişimin ortaya çıkardığı iletişimsel devrimin 'söz ve söylem' iktidarının kimi zaman zorbalığa varan sanal evreninin dilidir. $\mathrm{Bu}$ 'sanal evrende' çeşitlenen iletişim formları ile üretilen 'enformatif bilgi' klasik tasniflerde yer alan hiçbir epistemik çerçeveye dahil edilemeyecek türden bir 'bilgi' üretmektedir. Pandemi döneminde bu bilgi türü, üretmiş olduğu kirli/zararlı içeriği imlemek üzere 'infodemi' olarak adlandırılmıştır.

Farklılaşan dinamiklerini özetle ifade etmiş olduğumuz Covid-19 pandemisi, doğrudan 'kriz durumuna' neden olan etkenler başta olmak üzere, bu kriz ile mücadele kapasitesi olarak 'yeni bir kamusal aklın' icadı noktasında derin bir düşünüme kapı aralamıştır. Sözünü ettiğimiz 'yeni kamusal akıl', 'siyasal sistemlerden ekonomik düzenlere; piyasa ekonomisinden sanat politikasına; hukuk anlayışından iletişim stratejilerine; sosyal yaşam pratiklerinden eğitim politikasına; hak ve özgürlükler siyasetinden kentleşme düzenine varıncaya kadar birçok alanda bütün olarak yeni arayışları tetikleyen düşünsel süreçlerin bir hasılası olarak nitelendirilebilir. 
Bu çalışmaya konu edindiğimiz, sosyal haklar² kapsamında tasnif edilen 'sağlık hakkı', ufukta beliren düşünümselliğin dikkat çekici bir konusu olarak karşımızda durmaktadır. Burada ilgili hak konusunu problematize etmeyi gerekli kılan birincil etken kuşkusuz, 'sağlık' meselesinin tüm yönleriyle pandemi ile mücadelenin merkezi unsurunu oluşturmasıdır. 'Sosyal haklar, sağlık hakkı, sağlık güvencesi, sağlık sistemi ve sağlık hizmeti’ gibi temel meseleler pandeminin yol açtığı kamusal kaygının tetikleyici gücü ile pragmatik biçimde küresel bir tartışma zemini yaratmıştır. İçinde bulunduğumuz kriz halinin sıcaklığı ve yıkıcı etkisi altında da olsa bu konunun gündeme gelmesi gelecek adına ümit vericidir. Zira kapitalist modern liberal siyaset, hukuk ve ekonomik düzenin nihai zaferi ile sonlandığ düşünülen tarih tezlerinin, tarihsel gerçekliği ve dinamiği 1skaladığ görülmüştür. Öyle ki tarihsel gerçeklik, daha birçok tarihsel anlatıyı sahneye sokma potansiyelini bağrında taşıdığını her bir krizde olduğu üzere, pandemi krizinde de acı biçimde insanlara anlatmıştır.

$\mathrm{Bu}$ çerçevede olmak üzere, varoluşsal anlamda insan olmanın metafiziksel istinatgâhı olan 'insan onurunun' koruyucu kalkanı olarak hak ve özgürlüklere ilişkin tasavvur da sözünü etmiş olduğumuz krizin esaslı gündemlerinden birisini oluşturmaktadır. Zira her şeyden önce pandemi riskinin kendinde icbâriliği ile tevessül edilen 'istisnâi yönetim' usulleri ve bunun post-pandemik dönem için yönetsel rutine dönüşme olasıllğ̆ gündemi kamusal entelektüelliğin tartışma zeminine taşımaktadır. $\mathrm{Bu}$ bağlamsal çerçevede burada, modern insan hakları öğretisi ve uygulamasına egemen olan birinci kuşak haklar kataloğunun muhkem çerçevesinin dışında varlık mücadelesini sürdüren ikinci kuşak haklar olarak tanımlanan 'ekonomik, sosyal ve kültürel haklar' kapsamında yer alan sağlık hakkını sosyo-legal dinamiği açısından konu edineceğiz.

2 Bir insan hakkı olarak 'sosyal hakların' tarihsel arkaplanı ve ilgili hakların etkili korunmasına ilişkin kavramsal çözümleme için bkz., Ertan, İzzet Mert (2015) Sosyal Hakların Uluslararası Korunması ve Avrupa Sosyal Şartı Sistemi, İstanbul, Beta Yayıncılık, s. 6-26. Ayrıca bkz., Algan, Bülent (2007) Ekonomik, Sosyal ve Kültürel Hakların Korunması, Ankara, Seçkin Yayınları. 


\section{HAKLAR DİYALEKTIĞ̈̇: HAK KUŞAKLARINA İÇKİN NORMATIF DİNAMIKK}

İnsan hakları, birey karşısında devletin ilgili haklara ilişkin olarak yükümlülük çerçevesini belirleyen statüsel durum üzerinden klasik bir sınıflandırmaya tâbi tutulmuştur. Negatif ve pozitif sorumluluk/yükümlülük durumunu belirleyen bu sinıflamanın ilk örneğini ünlü hukuk kuramcisı Georg Jellinek ortaya koymuştur. ${ }^{3}$ Jellinek'in birey hakları bağlamında kaydettiği statüsel sınıflandırma; negatif (status negativus), pozitif (status positivus) ve aktif (status activus) statü haklarını içermektedir. Bunlardan özellikle aşağıda sözünü edeceğimiz negatif statü hakları, 'bireyin özgürlük alanını' deyimlemektedir. Öte yandan pozitif statü hakları ise, toplumun yararına uygun biçimde devletin sosyal alanda birtakım yükümlülükler üstlenmesini ifade etmektedir. ${ }^{4}$

İnsan hakları öğretisinde birincil hak kategorisi olarak sınıflandırılmış olan 'medeni ve siyasi haklar', birey karşısında devlete 'müdahalede bulunmama' ilkesi doğrultusunda 'negatif sorumluluk yükleyen haklar kuşağını ifade etmektedir. Bu hak kuşağının normatif dinamiği, ilgili haklar alanında devletin 'pasif ve negatif bir tutum' sergilemesidir. Bir anlamda bu alan, kamu otoritesi açısından 'yasak bölge' olarak tanımlanmıştır. Tarihsel arka plan açısından 18. yüzyılda varlık gösteren söz konusu klasik özgürlükler, literatürde 'negatif özgürlükler' olarak nitelendirilmiştir. ${ }^{5}$

'Negatif yükümlülük' doğuran bu özgürlükler, herhangi bir 'devletin müdahaleden kaçınmasını ve dolayısıyla insan haklarına saygı göstermesini' gerekli kılan bir sorumluluktur. Bu sorumluluk çerçevesinde devletler örneğin, "işkenceden (3. madde) ve ifade özgürlüğüne müsaade edilmeyen sınırlamalardan (10. madde) kaçınma” yükümlülüğü altındadır. Bu türden kamusal yükümlülükler, tipik olarak 'medeni ve siyasi haklara' özgüdür. O

Bkz., Gözler, Kemal (2017) İnsan Hakları Hukuku, Bursa, Ekin Yayınları, s. 152-154.

Konuya ilişkin ayrıntılı bilgi için bkz., Güngören Bulgan, Birden (2020) Georg Jellinek'in Hak ve Devlet Kuramı, 2. Baskı, İstanbul, On İki Levha Yayıncılık, s. 47-55.

5 Kapani, Münci (1993) Kamu Hürriyetleri, Ankara, Yetkin Yayınları, s. 50. 
nedenle, Sözleşme'nin (AİHS) taraf devletlere getirmiş olduğu yükümlülüklerin çoğu bir tür 'kaçınma' sorumluluğu getirmektedir. ${ }^{6}$

On sekizinci yüzyılda Amerikan ve Fransız devrimlerinin tarihi tektonik etkisi neticesinde 'negatif özgürlükler' üzerinden insan hakları kataloğunun normatif biçimlenmesi gerçekleşmiştir. Normatif biçimlenme süreci, trajik tarihsel hak ve özgürlük mücadeleleri yoluyla başarılı biçimde sonuçlanmıştır. $\mathrm{Bu}$ mücadele neticesinde elde edilen birincil alan, daha sonrasında 'birinci kuşak haklar' olarak literatürel tanımlamaya mazhar olmuştur. Modern insan hakları düşüncesinin kurucu figürlerinden olan John Locke'un düşünsel çerçevesi üzerinden klasikleşen formu ile bu klasik haklar, 'yaşam, mülkiyet ve özgürlük’ üçlemesi üzerinden yapılandırılmıştır.

Bunun ardından yine kökeninde sınıfsal bir mücadelenin yer aldığı 'ekonomik, sosyal ve kültürel haklar' da farklı tarihsel ve sosyolojik dinamikler ve mücadele biçimleri üzerinden normatif varlığına kavuşmuştur. Bu hakların, tarihsel köklerinin izini 19. yüzyıla kadar sürmemiz mümkün olmakla birlikte, bir hak kataloğu olarak anayasalarda pozitif bir varlığa kavuşması yirminci yüzyılın özellikle ikinci yarısına tesadüf etmektedir. ${ }^{8}$ Siyasi tarih açısından değerlendirildiğinde, bu hak kategorisine dahil olan hak türleri, özellikle ikinci dünya harbi sonrası dönemde liberal siyasal sistemlerin kendilerini konsolide etme yolundaki revizyonist tutumlarının bir tezahürü olarak yorumlanabilir. 'Adalet' temelinde kurgulanan bu revizyonist tutum kendisini, yine liberal siyasal felsefenin içinde kalarak 'sosyal adalet' olarak tanımlamıştır. 'Sosyal adalet', sanayi devriminin yarattığ 1 sosyo-ekonomik ve sosyo-kültürel dinamiklerle birlikte ortaya çıkan sınıfsal çatışmalar ve adaletsizliklerin tetiklemiş olduğu tarihsel huzursuzluklar karşısında siyasal sistemlerin yapısal bünyede bir ehlileştirme çabası olarak doğmuştur. Her ne kadar Hayek, adalet

6 Bkz., Harris, D. J./O’Boyle, M./Bates, E. P./Buckley, C. M. (2013) Avrupa İnsan Hakları Sözleşmesi Hukuku (Çeviren: Ed. H. Dinçer), Avrupa Konseyi, s. 19.

7 "Herkes eşit ve bağımsız olduğundan, hiç kimse diğerinin yaşamına, sağlığına, özgürlüğüne ya da malvarliğına zarar vermemelidir.” Bkz., Locke, John (2004) Yönetim Üzerine İkinci İnceleme (Çeviren: Fahri Bakırcı), Ankara, Babil Yayıncılık, s. 7.

8 Siyasi tarihte sosyal hakların pozitif hukuka geçiş süreci konusunda ayrıntılı bilgi için bkz., Kapani, s. 53-60. 
kavramının 'sosyal' nitelemesi ile kavramsallaştırılmasının anlamsızlı̆̆ını vurgulasa da 'sosyal adaleti' ortaya çıkaran tarihsel durumun bir ahlaki zemine dayandığını kabul etmektedir. ${ }^{9}$

Özdeşleşik bir aksiyolojik zemin üzerinden kavramsallaştırılan insan hakları, ilk iki hak kuşağının yanı sıra tarihsel dinamikleri ve referansları açısından farklılaşan üçüncü ve dördüncü kuşak haklar da dahil olmak üzere, bütünsellik ${ }^{10}$ arz eden bir fikri temel üzerine kurulmuştur. Nitekim Jack Donnelly'nin isabetle tespit ettiği üzere literatürde yer alan bu ikili ayrımın, kuşaklar arasında 'karşıtlık ve bağlantısızlık' düşüncesi yaratması doğaldır. Ancak tarihsel kökenine ilişkin dinamiklerden bağımsız olarak ilgili hakların evrimsel biçimde bütünselleşme yönünde evrildiği görülmektedir. Nitekim özellikle Batı Avrupa'da 'refah devleti' uygulamaları doğrultusundaki siyasal pratik ile birlikte ikinci kuşak haklara ilişkin tartışmalar anlamını büyük ölçüde yitirmiştir. ${ }^{11}$ Tarihsel referansları açısından değerlendirildiğinde 'refah devleti' (etat-providence; welfare state; sozialstaat) 18. yüzyılın sonlarından itibaren Avrupa uluslarının (Fransa, İngiltere ve Almanya) ${ }^{12}$ farklı sanayileşme tecrübeleri üzerinden bir siyasal restorasyon olarak ortaya çıkmıştır.

Yukarıda sözünü etmiş olduğumuz fikri zeminin kurucu kavramsallaştırması, 'insan onuru' (human dignity) ${ }^{13}$ olarak kaydedilmelidir. Felsefi bağlamda 'onur' (haysiyet, özsaygı, şeref vd.) terimi, bizatihi kişinin 'kendi imgesine uygun davranma ve yaşama bilincine' eşlik eden yaşam pratiğinin yine kişide 'belirli bir muamele beklentisi' yaratmasını ifade

9 Bkz., Hayek, F. A. (2013) Law, Legislation and Liberty, London and New York, Routledge, s. 226 vd. Ayrıca bkz., Aktaş, Sururi (2018) Hayek'in Hukuk ve Adalet Teorisi, 2. Baskı, Ankara, Liberte Yayınları, s. 232.

10 Hak kuşaklarının değerlendirilmesinde 'bütünsellik ilkesi' konusunda bkz., Uygun, Oktay (2019) Devlet Teorisi, 6. Baskı, İstanbul, On İki Levha Yayıncılık, s. 497 vd.

11 Donnelly, Jack (1995) Teoride ve Uygulamada Evrensel İnsan Hakları (Çeviren: Mustafa Erdoğan; Levent Korkut), Ankara, Yetkin Yayınları, s. 38-40.

12 Rosanvallon, Pierre (2004) Refah Devletinin Krizi (Çeviren: Burcu Şahinli), Ankara, Dost Kitabevi Yayınları, s. 119. Ayrıca bkz., Balcı Gökçeoğlu, Şebnem (2007) Tutunamayanlar ve Hukuk, Ankara, Dost Kitabevi Yayınları, s. 21-25.

13 Donnelly'nin de belirttiği üzere, Uluslararası İnsan Hakları Belgelerinde insan haklarının “insan kişisinin özündeki onurdan” kaynaklandığı kaydedilmektedir. Bkz., Donnelly, s. 27. 
etmektedir. Bu noktada 'onur', 'kişinin kendi imgesine uygunluğu' ile tezahür eden bir durum olarak kişinin kendisine biçtiği 'değere’ karşılık gelmektedir. ${ }^{14}$ Bir bütün olarak insan haklarının 'metafiziksel istinatgâhi' olarak nitelendirdiğimiz 'insan onuru', bireyin yalnızca yaşam kalitesini yükseltmesi bakımından değil, bizatihi kişiliğini ya da öz benliğini gerçekleştirebilmesinin varoluşsal zemini olması açısından da esaslı bir yer teşkil etmektedir. Söz konusu varoluşsal durum, kuşkusuz bir bütün olarak hakların diyalektiksel ilişkisi üzerinden yapılandırılması ile mümkün olabilecektir.

Nitekim birinci kuşak haklarla olan zorunlu organik ilişkisi üzerinden sosyal haklar, kişinin onuru zedelenmeden 'doğuştanlık ilkesi' doğrultusunda bireyin sahip olduğu hakların gereğini icra edebilme kapasitesini mümkün kılabilecektir. Bu meyanda, anayasal düzenlemelerde kendilerine yer bulmuş olan 'eğitim hakkı', 'sağlık hakkı', 'sosyal güvenlik hakkı' ve 'konut hakkı' gibi hakların yanı sıra, henüz 'beslenme hakkı' gibi anayasallaşmamış çok sayıda yeni hak kategorisinden söz edilebilecektir. Çağın dinamikleri ve toplumsal talepler doğrultusunda insan hakları literatürüne konu olan her bir yeni hak kategorisi, tüm kavramsal içerimiyle 'insan onurunu' tahakkuk ettirme amacına matuf olarak değerlendirilebilecektir.

Onur sahibi bir varlık olarak insanca yaşam sürebilmenin tahkim edici güvencesini oluşturan sosyal hakların insan hakları literatüründe birinci kuşak hak kategorisinden niteliksel anlamda ayrıştığına dair tez, söz konusu hakkın kırılgan doğasını tahkim edici niteliktedir. Öğretide ilgili tez, bu hakların 'soyutluk', 'bağımlılık', 'tedricilik', 'ahlaki görev oluşturmak' ve 'dava edilebilirlik' nitelikleri üzerinden tanımlanmıştır. ${ }^{15} \mathrm{Bu}$ türden tezlere karşı olmak üzere, Viyana'da 25 Haziran 1993 tarihinde 'Dünya İnsan Hakları Konferansı' tarafından kabul edilen 'Viyana Deklarasyonu ve Eylem Programi', kuramsal açıdan insan haklarının bütünleşik yapısına dikkat çekmiştir. Bu noktada insan hakları, evrensel (universal), bölünmez (indivisible) ve birbirine bağımlı ve birbiriyle ilişkili (interdependent and interrelated) olan haklardan

14 Kuçuradi, İonna (1999) Etik, Ankara, Türkiye Felsefe Kurumu Yayınları, s. 162.

15

Ayrıntılı bilgi için bkz., Şahin, Adil (2010) "Ulusalüstü İnsan Hakları Hukukunda Ekonomik Sosyal ve Kültürel Hakların Niteliği Bağlamında Sağlık Hakkının Kapsamı Üzerine Bir İnceleme”, Ankara Üniversitesi Hukuk Fakültesi Dergisi, C: 59, S: 4, s. 722. 
müteşekkildir. Buna göre uluslararası toplum, insan haklarını küresel olarak adil ve eşit biçimde, benzer bir temelde ve eş vurguyla dikkate almalıdır. Ulusal ve bölgesel özelliklerin ve çeşitli tarihi, kültürel ve dini geçmişlerin önemi göz önünde bulundurulmakla birlikte, siyasi, ekonomik ve kültürel sistemlerinden bağımsız olarak tüm insan haklarını ve temel özgürlükleri teşvik etmek ve korumak devletlerin temel sorumluluğu olarak belirlenmiştir. ${ }^{16}$

\section{HAKLAR DİYALEKTİĞİ AÇISINDAN SAĞLIK HAKKI}

Literatürel bir sınıflama olan 'hak kuşaklarının' içkin normatif dinamikleri açısından 'sağlık hakkı' konunun çerçevesinin somutlaştırılması noktasında elverişli bir zemin sunmaktadır. Bu meyanda insan hakları doktrininde, 'bütünlükçü' teorik yaklaşımların karşısında 'ayrıştırıcı' tezlerin temel argümanları üzerinden yürütülecek olan tartışma daha anlamlı bir çerçeve ortaya koymaktadır.

Bütün 'ayrıştırıcı' öğretisel değerlendirmelere ve tezlere rağmen, 'ekonomik, sosyal ve kültürel haklar' kataloğu, başta birinci kuşak haklar olmak üzere bütün hak kategorileri ile 'organik bir ilişkiselliğe' sahiptir. Bu kapsamda olmak üzere, yaşamsal bir hak olarak 'sağlık hakkı' da böylesi organik bir bağ ile diğer hak alanlarıyla doğrudan ilişkilidir. Bu yaşamsal hak, öngördüğü 'pozitif yükümlülükler' ile devletin bireyleri koruyucu birtakım tedbirler almasını gerekli kılmaktadır. Ancak söz konusu yükümlülükler, 'devletin mali kaynaklarının yeterliliği' ölçüsü ${ }^{17}$ ile kayıtlanmıştır. Nitekim Avrupa İnsan Hakları Mahkemesi (AİHM) de bu çerçevede alınacak

16 Bkz., World Conference on Human Rights, "Vienna Declaration and Programme of Action”, Vienna, 14-25 June 1993, https://www.ohchr.org/Documents /ProfessionalInterest/vienna.pdf, s.e.t. 23.05.2020.

17 'Devletin iktisadi ve sosyal ödevlerinin sınırlarını' belirleyen Anayasanın 65. Maddesine göre; "Devlet, sosyal ve ekonomik alanlarda Anayasa ile belirlenen görevlerini, bu görevlerin amaçlarına uygun öncelikleri gözeterek malî kaynaklarının yeterliliği ölçüsünde yerine getirir." 
önlemlere ilişkin yükümlülügün 'imkânsız veya orantısız' olacak biçimde yorumlanmaması gerektiğini vurgulamıştır. ${ }^{18}$

Anayasa sistematiğimizde bu 'organik ilişkisellik', özellikle anayasal ilkelerin kavramsal içeriminde göze çarpmaktadır. Öyle ki, 'sosyal adaleti' tahakkuk ettirebilmenin ilkesel imkânı ${ }^{19}$ olarak Anayasamızın 2. maddesindeki ${ }^{20}$ 'sosyal devlet' prensibi, sağllk hizmetinin belirli bir 'erişilebilirlik' ve nitelik düzeyinde kamusal bir hizmet olarak yurttaşlara sunumu açısından âmir bir hüküm olarak değerlendirilebilir. İlgili anayasal ilke doğrultusunda devletin sahip olduğu mali kaynakların yeterliliği ölçüsünde bu hakların gereğini yerine getirmesi öngörülmektedir. $\mathrm{Bu}$ çerçevede devletin kamu sağlığını koruma adına tedbir olarak önleyici sağlık hizmetleri ve sağlık yatırımları yapması icap etmektedir. Sözünü etmiş olduğumuz bütün bu gereklilikler, diğer haklar kuşağının normatif güvencesini tahkim adına hayati bir önemi haizdir.

$\mathrm{Bu}$ noktada John Locke, yönetim felsefesini temellendirmiş olduğu argümanlarında, siyasal yönetimin 'özel bir yasayla herhangi bir kimsenin yoksullaşmamasını ya da hastalanmamasını temin edemeyeceğini ancak, siyasal yönetimin regülatif aracı olan yasalar ile "mümkün olduğu kadar, vatandaşların mülkiyetinin ve sağhlğının başkalarının sahtekarlığı ve şiddeti yüzünden zarar görmemelerini sağlayabileceğini” belirtmektedir. ${ }^{21}$ Burada Locke, en azından kamu sağlığına yönelecek tehdit karşısında bir yasal güvence mekanizması öngörmektedir.

Temelinde bu tartışmayı, bir 'haklar dizgesi olarak hukuk' üzerinden yürütülen bir tartışma olarak nitelendirebiliriz. Nitekim modern dönem hukuk düşünürlerinden Dworkin bu çerçevede bütünlüklü bir hak/hukuk

Bkz., Harris/O’Boyle/Bates/Buckley, s. 45.

19 Bkz., Aktaş, s. 224-225.

20 Anayasanın Cumhuriyetin niteliklerini tâdat eden ikinci maddesinde bu ilkeye şöyle yer verilmiştir; "Türkiye Cumhuriyeti, toplumun huzuru, milli dayanışma ve adalet anlayışı içinde, insan haklarına saygıll, Atatürk milliyetçiliğine bağll, başlangıçta belirtilen temel ilkelere dayanan, demokratik, laik ve sosyal bir hukuk Devletidir."

21 Locke, John (2012) Hoşgörü Üstüne Bir Mektup (Çeviren: Melih Yürüşen), 5. Baskı, Ankara, Liberte Yayınları, s. 46. 
tasavvuru geliştirmiştir. Hukuku, yargılama sürecinde savunulan haklar bütünü olarak değerlendiren Dworkin, yargıçlar gibi tüm devlet görevlilerinin hakları 'ciddiye alması' gerektiğini vurgulamıştır. ${ }^{22}$ Düşünür, demokratik siyasallığa dair, 'çoğunlukçu ve ortaklık demokrasisi' olmak üzere iki farklı demokrasi yaklaşımından söz etmiştir. Halkın çoğunluğunun halkın geri kalan kısmını yönetme biçimi olarak 'çoğunlukçu demokrasi' ile bir şirket veya ortaklığa benzer biçimde halkın kendi kendini yönetmesi usulü olarak 'ortaklık demokrasisi' arasındaki ayrışma noktalarına temas etmiştir. ${ }^{23}$

$\mathrm{Bu}$ doğrultuda Dworkin, dünya anayasalarında özellikle 'temel sağlık güvencesi' ya da 'yaşanabilir konut hakki' gibi ekonomik ve sosyal hakların güvence altına alınması noktasındaki ayrışan yönlere dikkat çekmiştir. Sözü edilen güvenceler açısından değerlendirildiğinde Amerika Birleşik Devletleri (ABD) Anayasası'nın herhangi bir güvenceye yer vermediğini kaydetmiştir. Siyasal sistem açısından 'çoğunlukçu demokratik' yönetimlerin anayasal sistemlerinde bu tür güvencelere veya hükümlere yer vermediğini öne sürmüştür. Çoğunluğun yerleşik iradesi tarafından karara bağlanması gereken konular kategorisinde olmasından ötürü sosyal haklara ilişkin güvencelerin anayasalarda yer alması uygun görülmemiştir. Zira sosyo-ekonomik konular, 'bütçe, kaynakların bölüşümü ve vergi sistemi' gibi temel meselelerde politik bir tercihi gerekli kılmaktadır. 'Çoğunlukçu demokrasilerde', söz konusu politik tercihler, halkın seçilmiş temsilcileri tarafından gerçekleştirilmektedir. Diğer yanda 'ortaklık demokrasisinde' ise söz konusu haklar, güvence altına alınmak durumundadır. Zira adı geçen haklar, bir anlamda demokrasinin ön koşulu niteliğindedir. ${ }^{24}$

Sonuç olarak, hak kuşakları arasındaki diyalektiksel dinamik, insan haklarının sancılı tarihsel serencamının merkezi mücadele alanını oluşturan 'medeni ve siyasi' haklar ile diğer kuşak haklar arasındaki ilişkiye dair politik perspektifte kendisini açığa çıkarmaktadır. Bütünselci doktriner perspektiften

22 Bkz., Dworkin, Ronald M. (2007) Hakları Ciddiye Almak (Çeviren: Ahmet Ulvi Türkbağ) Ankara, Dost Kitabevi Yayınları, s. 223 vd.

23 Dworkin, Ronald M. (2011) "Siyasal Anayasanın Ahlaki Temelleri”, Anayasa Yargısı Dergisi, S: 28, s. 28.

Dworkin, Ronald M. (2011), s. 32. 
değerlendirildiğinde, sağlık hakkının diğer sosyal hak türleri ile birlikte eklemlendiği haklar dizgesinin, bu dinamik üzerinden demokratik siyasal sistemlerde bir 'talep meşruiyeti' yarattığı söylenebilir. Nitekim Dworkin'in çerçevesini çizmiş olduğu 'ortaklık demokrasisi' böylesi bütüncül bir hak/lar felsefesi öngörmektedir.

\section{SAĞLIK HAKKININ ULUSALÜSTÜ NORMATİF ÇERÇEVESİ}

İçeriğinde yer alan haklar listesi ve kavramsal içerimi itibariyle homojenitesi olmayan bir hak kataloğu olarak nitelendirilebilecek olan sosyal haklar ${ }^{25}$ kapsamında yer alan 'sağlık hakkına', ilk kez Birleşmiş Milletlerin (BM) uzmanlık birimlerinden birisi olan Dünya Sağlık Örgütü (WHO) ${ }^{26}$ Anayasası yasal bir çerçevede yer vermiştir. Bu bağlamda WHO'nun 1946 tarihli Anayasal belgesinde sağlık, 'bir bütün olarak fiziksel, ruhsal ve sosyal esenlik durumu' olarak tanımlanmıştır. Burada fiziksel ve ruhsal bir bütünlük olarak tanımlanan insanın herhangi bir 'hastalık ya da maluliyetten âri olması' sağlıklı olmanın kriteri olarak kabul edilmiştir. Örgüt, sosyal haklar bağlamında devletlerin 'pozitif yükümlülüklerine' de işaretle sağlık hakkını şu ifadelerle temel bir hak konusu olarak düzenlemiştir. "Ulaşılabilir en yüksek

25 Bkz., Bulut, Nihat (2009) Sanayi Devriminden Küreselleşmeye Sosyal Haklar, İstanbul, On İki Levha Yayıncilık, s. 60-61.

Dünya Sağlık Örgütü (World Health Organization -WHO) Birleșmiş Milletlere bağlı olan ve sağlı̆̆1 geliştirmek, dünyayı güvende tutmak ve savunmasız kişilere hizmet etmek için uluslararası çalışmalar yapan bir örgüttür. Dünya Sağlık Örgütü (WHO) 7 Nisan 1948 tarihinde 'sağlığın bir insan hakkı olduğu' ve tüm insanların en yüksek sağlık standardından yararlanmaları gerektiği ilkesi üzerine kurulmuştur.

Bkz.,https://www.euro.who.int/en/about-us/organization/who-at-70/milestones-for-healthover-70years Örgüt, sağlık hakkının tanımlanması noktasında ilk normatif adımı atmış olmasına rağmen, süreç içerisinde bu hakkın normatif içerimini geliştirme doğrultusunda girişimsel yetkisini kullanmamıştır. Bkz., Ertan, İzzet Mert (2012) Uluslararası Boyutlarıyla Sağlık Hakkı, İstanbul, Legal Yayınevi, s. 15. Bu yönüyle eleştirilen Örgüt, Covid-19 salgını döneminde de pandemik krizi yönetmedeki yetersizlikleri açısından dünya kamuoyunda ciddi eleştirilerin odağı olmuştur. Özellikle ABD Başkanı Donald Trump, 'koronavirüsün yayılmasını gizleme ve süreci iyi yönetmeme' gerekçeleriyle WHO’ya yönelik bir soruşturma başlatılacağını duyurmuştur. Bkz., https://www.bbc.com/news/world-uscanada-52289056, s.e.t. 29.05.2020. 
sağlik standartlarından yararlanma; ırk, din, siyasi görüş, ekonomik ya da sosyal durum farkı gözetilmeksizin her insanın temel haklarından biridir."27

Sağllk hakkının ${ }^{28}$ bildirgesel normatif çerçevesi ise, 1948 tarihli 'Evrensel İnsan Hakları Bildirgesi'nin 25. maddesinde görece kapsamlı bir sosyal haklar kataloğu üzerinden düzenlemeye konu olmuştur. ${ }^{29} \mathrm{Bu}$ düzenleme sağlık hakkını, kendi başına bir hak olarak ele almaktan ziyade, 'yaşam/a standardı hakkının' bileşenlerinden birisi olarak değerlendirmiştir. ${ }^{30}$ Bildirge, insan haklarının bütünselliğinin bir göstergesi olmanın ötesinde, aynı zamanda sağlık hakkının yakın ilişki içinde olduğu diğer haklara da işaret etmiştir. ${ }^{31}$

Bir başka düzenleme 1966 tarihli 'Uluslararası Ekonomik, Sosyal ve Kültürel Haklar Sözleşmesinin’ (ICESCR) ilgili 12. maddesinde yer almıştır. İlgili düzenleme ile Sözleşmeye taraf devletler, etkin erişilebilirlik düzeyinde insanların 'en yüksek standartta fiziksel ve ruhsal sağlık hizmetlerinden

27 Basic Documents: forty-ninth edition (including amendments adopted up to 31 May 2019). Geneva: World Health Organization; 2020, https://apps.who.int/gb/bd/pdf_files/BD_49then.pdf\#page $=7$

Sağlık hakkının tarihsel süreci için bkz., Porter, Dorothy (1999) Health, Civilization and the State: A History of Public Health From Ancient to Modern Times, London, New York. Tarantola, Daniel (2008) "A Perspective on the History of Health and Human Rights: From the Cold War to the Gold War", Journal of Public Health Policy, Vol: 29. Azarkan, Ezeli (2018) Uluslararası Hukukta Sağlık Hakkı, Ankara, Seçkin Yayıncılık, s. 47-49.

"Herkesin, yiyecek/(beslenme), giyim, konut, tıbbi bakım ve gerekli sosyal hizmetler dahil olmak üzere, kendisinin ve ailesinin sağlık ve refahını/(esenliğini) temin için, yeterli bir yaşama standardına (sahip olma) hakkı ve işsizlik, hastalık, maluliyet/(sakatlık), dulluk, yaşlılık hallerinde ya da geçim olanaklarından kendi kontrolü dışındaki koşullardan doğan diğer yoksunluk durumlarında, (sosyal) güvenceye (sahip olma) hakkı vardır. 2. Analık ve çocukluk (durumları), (ana ve çocuğu) özel bakım ve yardım görmeye hak sahibi kılar. Tüm çocuklar, ister evlilik içinde isterse evlilik dışında doğmuş olsun, aynı sosyal korumadan yararlanacaklardır." 10 December 1948 dated, Universal Declaration of Human Rights Article 25, https://www.ohchr.org/EN/UDHR/Documents/UDHR_Translations/eng.pdf

30 Marks, Stephen P. (2013) "Emergence and Scope of the Right to Health", In Advancing the Human Right to Health, (ed. José M. Zuniga, Stephen P. Marks, and Lawrence O. Gostin), Oxford University Press, p. 8.

Bkz., Ertan (2012), s. 18-20. 
yararlanma hakkını' tanımakla yükümlendirilmiştir. Taraf Devletlere, ${ }^{32}$ yurttaşların bu haktan tam anlamıyla yararlanabilmeleri için birtakım önlemler almaları yükümlülüğü getiren düzenlemelere yer verilmiştir. Bu kapsamda olmak üzere ilgili düzenlemede, 'çocuğun sağlıklı gelişimi'; 'çevresel ve sınâi sağlık şartlarının iyileştirilmesi'; 'salgın ve diğer hastalıkların önlenmesi, tedavisi ve denetim altında tutulması'; 'bütün sağlık hizmetlerini ve tıbbi bakımı temin edecek koşulların yaratılması' gibi birtakım sağlık tedbirleri öngörülmüştür. ${ }^{33}$ Sözleşme’ye 5 Mayıs 2013 tarihinde eklenerek yürürlüğe giren Ek İhtiyarî Protokol ${ }^{34}$ ile sağlık hakkını da içerir biçimde 'ekonomik ve sosyal hakların' uluslararası hukuk bağlamında daha güvenceli hale getirilmesi yönünde kurumsal bir adım atılmıştır. Bu somut adım, ilgili hakların 'dava edilebilirliğine' ilişkin normatif bir güvence yaratmıştır. ${ }^{35}$

Nitekim bu meyanda 'Ekonomik, Sosyal ve Kültürel Haklar Komitesinin' (Committee on Economic, Social and Cultural Rights), yayınlamış olduğu 'Genel Yorum'da (General Comment) sağlık hakkının değerlendirilebilmesi noktasında dört temel kriter belirlenmiştir. Bu kriterler; 'varlık, erişilebilirlik, kabul edilebilirlik ve kalite’ olarak sıralanmıștır. Birinci kriter, 'işler halde halk

32 Başta Almanya, Fransa, İspanya ve Türkiye olmak üzere sözleşmenin 170 taraf ülkesi bulunmaktadir.

https://treaties.un.org/Pages/ViewDetails.aspx?src=IND\&mtdsg_no=IV-

3\&chapter $=4 \&$ clang=_en, s.e.t. 22.05.2020.

Madde 12/1. “Bu Sözleşmeye Taraf Devletler, herkesin ulaşılabilir en yüksek düzeyde fiziksel/(bedensel) ve ruhsal sağllk standartlarından yararlanması hakkını tanır. 2. Bu Sözleşmeye Taraf Devletlerce bu hakkın tam olarak gerçekleştirilmesini sağlamak için alınacak önlemler: (a) Ölü doğum oranının ve çocuk ölümlerinin düşürülmesi ve çocuğun sağlıklı gelişmesinin sağlanmasi; (b) Çevresel ve sınai să̆lık şartlarının bütün yönleriyle iyileștirilmesi; (c) Salgin, yöresel, mesleki ve diğer hastalıkların önlenmesi, tedavisi ve denetim altında tutulması; (d) Hastalık durumunda bütün sağlık hizmetlerini ve tıbbi bakımı temin edecek koşulların yaratılması, için gerekli bulunan önlemleri de kapsayacaktır." 16 December 1966 dated, International Covenant on Economic, Social and Cultural Rights, https://www.ohchr.org/Documents/ProfessionalInterest/cescr.pdf, s.e.t. 22.05.2020.

Optional Protocol to the International Covenant on Economic, Social and Cultural Rights, https://www.ohchr.org/Documents/HRBodies/CESCR/OProtocol_en.pdf, s.e.t. 22.05.2020.

Dericiler Yücel, Özge (2014) Sosyal Haklar ve İnsan Hakları Hukuku Çerçevesinde Devletin Yükümlülükleri: Refah Devletinin Krizi Ekseninde Bir İnceleme, İstanbul, On İki Levha Yayıncilık, s. 2. 
sağlığı ve sağlık bakımı kuruluşlarının, malzeme, servis ve programlarının' yeterli miktarda bulunmasına karşılık gelmektedir. 'Erişilebilirlik' kriteri, 'sağlık kuruluşlarının, malzemelerinin ve servislerinin ayrımcılık yapılmadan herkesin erişimine açık olmasını' gerekli kılmaktadır. Bu kriter, 'ayrımcılık yapmama', 'fiziksel, ekonomik ve bilgisel erişebilirlik' olmak üzere dört bileşenden oluşmaktadır. Kabul edilebilirlik kriteri; tüm sağlık kuruluşları, malzemeleri ve servislerinin tıbbi etiğe saygılı; kültürel olarak uygun, cinsiyete ve yaşam döngüsü gereklerine duyarlı; aynı zamanda hizmet alanların mahremiyetlerine saygı duyulacak ve onların sağlık seviyelerini yükseltecek biçimde tasarlanmış olmalıdır. Son olarak kalite kriteri ise, 'sağlık kuruluşları, malzemeleri ve servislerinin bilimsel ve tıbbi gereklere uygun ve iyi nitelikte' olmasını gerekli kılmaktadır. ${ }^{36}$

Benzer biçimde 1996 tarihli 'Gözden Geçirilmiş Avrupa Sosyal Şartı'nın ${ }^{37} 11$. maddesi, ilgili hak konusunu 'sağlı̆̆ın korunması hakkı' olarak tanımlamıştır. İlgili düzenleme, taraf ülkelerin bu hakkın etkin biçimde kullanılmasını sağlama hedefine matuf olarak birtakım önlemler sıralamıştır. $\mathrm{Bu}$ kapsamda olmak üzere; 'sağlığın bozulmasına yol açan nedenleri olabildiğince ortadan kaldırma'; 'sağlıklı yaşamı teşvik amacıyla danışma ve eğitim olanakları sağlama'; 'salgın/epidemik hastalıkları veya süreklilik arz eden/endemik hastalıkları ve diğer hastalıkları önlemeye’ yönelik tedbirlerin geliştirilmesi teklifi getirilmiştir. ${ }^{38}$ Bütün bunların dışında Avrupa Konseyi

36 Committee on Economic, Social and Cultural Rights, "General Comment No. 14: The Right to the Highest Attainable Standard of Health (Art. 12)", 11 August 2000.

37 Avrupa Sosyal Şartı hakkında ayrıntılı bilgi için bkz., Harris, David John/Darcy, John (2001) The European Social Charter, (Harris ve Darcy), 2nd ed., N.Y., Transnational Publishers.

Madde 11. "Sağlığın korunması hakkı Taraflar, sağlı̆̆ın korunması hakkının etkin biçimde kullanılmasını temin etmek amacıyla, ya doğrudan ya da kamusal yahut özel örgütlerle işbirliği yaparak, diğer önlemlerin yanı sıra: 1. sağllğın bozulmasına yol açan nedenleri olabildiğince ortadan kaldırmak; 2. sağlıklı olmayı geliştirmek ve sağlıkla ilgili konularda kişisel sorumluluk üstlenmeyi teşvik etmek üzere, danışma ve eğitim olanaklarını sağlamak; 3. salgın/(epidemik) hastalıkları, yöresel ve süreklilik arz eden/(endemik) hastalıkları ve diğer hastalıkları ve bunların yanı sıra kazaları mümkün olduğunca önlemek üzere tasarımlanmış uygun önlemleri almayı üstlenirler.” European Social Charter (Revised), 1996, Strasbourg. 
Belgeleri, Amerikan Devletleri Örgütü Belgeleri ile Afrika Birliği Belgelerinde de sağlık hakkına ilişkin düzenlemelere yer verilmiştir. ${ }^{39}$

$\mathrm{Bu}$ çerçevede olmak üzere, 2005 tarihli 'Uluslararası Sağlık Tüzü̆̆̈̈' (International Health Regulation), halk sağlı̆̆ açısından ortaya çıkabilecek olan riskle orantılı ve sınırlı olma koşulu ile 'hastalıkların uluslararası yayılımını önlemek ve kontrol etmek ve bu hastalıklara karşı korunmak' adına halk sağlığı açısından gerekli olan önlemleri alabilmek amacına matuf bir normatif çerçeve ortaya koymuştur. ${ }^{40}$ İlgili düzenlemenin 18. maddesine göre Dünya Sağlık Örgütü, halk sağlığını tehdit eden durumların gerçekleşmesi halinde, halk sağlığ 1 açısından risk oluşturabilecek şekilde enfekte ya da kontamine olmuş veya enfeksiyon ya da kontaminasyon kaynağı olan kişileri gözlem altına almak; karantina uygulaması yapmak; veya diğer sağlık önlemlerini almak; ve gerekli görüldügünde izolasyon ve tedavi uygulamasına başvurmanın gerekliliğini düzenlemiştir. Yine bu bağlamda olmak üzere 'şüpheli veya etkilenen kişilerin temaslarının izini sürmek; şüpheli ve etkilenen kişiler ile etkilenmemiş kişilerin etkilenen bölgelere girişine izin vermemek; ve etkilenen bölgelerdeki kişiler üzerinde çıkış taraması ve/ya kısıtlamalar uygulamak' gibi önlemler öngörülmüştür. ${ }^{41}$

\section{SAĞLIK HAKKININ KORUNMASINA YÖNELİK YARGISAL EĞİLIM}

Teorik kurgusu itibariyle Avrupa Sözleşmesi büyük oranda 'demokratik bir hayat biçimi için zorunlu olan' medeni ve siyasi haklar üzerine odaklanmıştır. Böylelikle, kısmen tartışmalı niteliğinden ötürü 'ekonomik, sosyal ve kültürel haklar', daha sonra hazırlanacak başka bir sözleşmeye

39 Ayrıntılı bilgi için bkz., Azarkan, s. 76-81.

40 World Health Organization (WHO) (2005) International Health Regulations, Third Edition, Switzerland, WHO Press, p. 10.

41 Ayrıntılı bilgi için bkz., International Health Regulations -Article 18, "Recommendations with respect to persons, baggage, cargo, containers, conveyances, goods and postal parcels", https://apps.who.int/iris/bitstream/handle/10665/246107/9789241580496-

eng.pdf?sequence $=1$ 
bırakılmıştır. ${ }^{42}$ Sözleşmesel düzeyde normatif çerçevesine kavuşarak öğretide 'ikinci kuşak haklar ${ }^{\text {‘3 }}$ olarak tanımlanan bu hak kataloğu, kuşkusuz 'tarihsel, sınıfsal ve sosyolojik referansları' açısından ilkinden farklılık arz etmektedir. Temel olarak bu hak kataloğunun 'sağlık hakkı' gibi birey karşısında devlete 'pozitif yükümlülükler' yükleyen hak türleri barındırdığını kaydetmeliyiz.

$\mathrm{Bu}$ teorik sinıflamaya uygun biçimde Mahkeme (AİHM) de 'negatif ve pozitif yükümlülükler' tipolojisine bağlı kalmaktadır. Bununla birlikte Mahkemenin, 'insan haklarına saygi, insan hakların koruma ve yerine getirme’ yükümlülüklerini kapsayan bir tipolojik üçlemeyi benimsediği görülmektedir. ${ }^{44} \mathrm{Bu}$ tipolojik üçleme yalnızca Mahkeme tarafından değil, Birleşmiş Milletler (BM) Ekonomik, Sosyal ve Kültürel Haklar Komitesi tarafından da yerleşik biçimde kullanılmaktadır. ${ }^{45} \mathrm{Bu}$ çerçevede tüm insan hakları kataloğu açısından geçerli olan, 'saygı, koruma ve yerine getirme' yükümlülüklerinin geçerliliğini sağlık hakkı için de kaydedebiliriz. Buna göre sayg1 duyma yükümlülüğü (respect), devletlerin sağlık hakkından yararlanmaya doğrudan veya dolaylı olarak müdahale etmekten kaçınmasını gerektirmektedir. Koruma yükümlülüğü (protect), ${ }^{46}$ devletlerin üçüncü tarafların 12. madde (Ekonomik, Sosyal ve Kültürel Haklar Sözleşmesi) garantilerine müdahale etmesini önleyici tedbirler almasını gerekli kılmaktadır. Son olarak, yerine getirme yükümlülüğü ( $f u l f i l l)$ ise, devletlerin

42 Bkz., Harris/O’Boyle/Bates/Buckley, s. 3.

43 İkinci kuşak haklar kataloğuna ilişkin ayrıntılı bilgi için bkz., Uygun, Oktay (2013) "İnsan Hakları Kuramı”, Kamu Hukuku İncelemeleri, 2. Baskı, İstanbul, On İki Levha Yayıncılık, s. $32 \mathrm{vd}$.

44 Bkz., Harris/O’Boyle/Bates/Buckley, s. 19.

Bu tipoloji, UN Doc E/CN.4/Sub.2/1987/23 (paragraf 67-68-69) ile formüle edilmiştir.

Koruma yükümlülükleri, diğerlerinin yanı sıra, devletlerin üçüncü taraflarca sağlanan sağlık hizmetlerine ve sağlıkla ilgili hizmetlere eşit erişim sağlayan mevzuat kabul etme veya diğer tedbirleri alma görevlerini; sağlık sektörünün özelleştirilmesinin sağlık tesislerinin, mallarının ve hizmetlerinin mevcudiyeti, erişilebilirliği, kabul edilebilirliği ve kalitesi için bir tehdit oluşturmamasını sağlamak; tıbbi cihaz ve ilaçların üçüncü taraflarca pazarlanmasını kontrol etmek; tıp pratisyenlerinin ve diğer sağlık profesyonellerinin uygun eğitim, beceri ve etik davranış kurallarına uymalarını sağlamayı içermektedir.

Bkz., Committee on Economic, Social and Cultural Rights, "General Comment No. 14." 
sağlık hakkının tam olarak gerçekleştirilmesi için uygun 'idari, mali, yasal, yargısal ve diğer önlemleri' almasını gerektirmektedir. ${ }^{47}$

Sözleşme’nin dayandığı temel hak felsefesi ve Mahkemenin (AİHM) ictihâdi eğilimi dikkate alındığında herhangi bir hak konusunun etkili bir güvenceye kavuşturulması adına kimi zaman 'negatif sorumluluk' ile 'pozitif yükümlülüğün’ bütünleşik biçimde değerlendirildiği görülmektedir. Örneğin 'kanunla yaşam hakkının korunması' (2 (1) maddesi) ile 'insanlık dışı olmayan cezaevi koşullarının sağlanmasi' (3. madde), bu 'bütünleşik sorumluluğu' ortaya koymaktadır. Mahkeme, ayrıca Sözleşme (AİHS) kapsamında bazı başka 'pozitif yükümlülükler' de ortaya koymuştur. Buna göre, Sözleşmenin 8 . maddesinde düzenlenen 'aile yaşamına saygı hakkı' kapsamında devlete 'negatif sorumluluğun' yanı sıra, 'etkili saygi' ilkesi çerçevesinde birtakım pozitif yükümlülüklerin getirilmesi de söz konusu olmuştur. Nitekim bu durumu ortaya koyan Marckx v. Belçika davası ${ }^{48}$ burada ilgi çekici bir yargı kararı olarak kaydedilebilir. ${ }^{49}$

Yüksek insan hakları yargısının dinamik doktriner eğilim doğrultusunda ortaya koymuş olduğu yargısal pratikleri, haklar arasındaki 'akışkan diyalektiği' ortaya koymaktadır. Nitekim Sözleşmenin ikinci maddesinde düzenlenen 'yaşam hakkı' ile 'sağlık hakkı' arasındaki organik bağa ilişkin olarak Calevelli ve Ciglio v İtalya davasına ${ }^{50}$ dikkat çekebiliriz. Mahkeme vermiş olduğu kararda ilgili 2. maddede düzenlenen 'yaşam hakkını' korumak için önlemler almaya yönelik 'pozitif yükümlülüğün', kamu sağlığı alanına da uygulanacağını teyit etmiştir. ${ }^{51}$

Evrensel Bildirge'nin 3. maddesi ${ }^{52}$ ve Avrupa İnsan Hakları Sözleşmesi'nin 2. maddesi ${ }^{53}$ ile Anayasamızın 'kişinin dokunulmazlı̆̆ , maddi

\footnotetext{
Committee on Economic, Social and Cultural Rights, "General Comment No. 14."

A 31 (1979); 2 EHRR 330 para 31 PC.

Bkz., Harris/O'Boyle/Bates/Buckley, s. 20.

Bkz., 2002-I para 49 ve 51.

Bkz., Harris/O’Boyle/Bates/Buckley, s. 42-43.

İHEB md. 3. "Herkesin yaşama hakkı ile kişi özgürlüğü ve güvenliğine hakkı vardır." AİHS md. 2. "Herkesin yaşam hakkı yasayla korunur..."
}

52 
ve manevi varlı̆ğ ${ }^{54}$ başlıklı düzenlemesi yaşam hakkını güvence altına almaktadır. Yaşam hakkı, demokratik toplumun varoluşsal dinamiği açısından koruma ve güvence mekanizması olarak öngördüğü birincil değerdir. ${ }^{55} \mathrm{Bu}$ hak, devletler üzerinde savaş veya herhangi bir olağanüstü durumda bile askıya alınmaması (derogation) gereken bir sözleşmesel yükümlülük doğurmaktadır. Söz konusu negatif yükümlülük, devletin kişi hakları açısından asli nitelikli bir değer olan yaşam hakkını ihlal edici tasarruflardan kaçınma sorumluluğuna karşılık gelmektedir. Ancak bununla da sınırlı olmaksızın, 'yasa' temelinde bir güvence mekanizması öngörülen bu temel hakkın korunmasına ilişkin pozitif yükümlülükler de söz konusudur.

'Sağlık hakkı' ile 'yaşam hakkı' arasındaki diyalektik gereği, yaşam hakkının korunmasına dair birtakım önleyici tedbirlerin alınması, taraf devletler için sözleşmesel bir yükümlülük olarak kabul edilmiştir. Nitekim bu durum, ilgili Mahkeme (AİHM) kararlarında ilkesel olarak düzenlenmiştir. LCB v Birleşik Krallık davasında ${ }^{56}$ Mahkeme devletin, "başvurucunun hayatına yönelebilecek tüm zararları önlemek için kendisinden beklenebilecek tüm önlemleri alma yükümlülü̆ğ altında" olduğunu karara bağlamıştır. ${ }^{57} \mathrm{Bu}$ yönüyle pozitif haklar bir anlamda, negatif hakların etkili biçimde yaşama geçirilebilmesinin aracı olarak kabul edilmiştir. ${ }^{58}$

Yine yaşamı korumak için 'uygun tedbirler alma' yükümlülüğü çerçevesinde 'sağlık hizmetleri' uygulaması gündeme gelmektedir. $\mathrm{Bu}$ bağlamda Kıbrıs v Türkiye davasında ${ }^{59}$ Kuzey Kıbrıs'ta yaşayan bazı Rum ve Marunilerin yeterli sağlık hizmetine erişim kısıtı iddiası ortaya çıkmıştır. Burada Mahkeme, Sözleşmenin 2. maddesinin 'sağlık hizmetlerinin sunulması' yükümlülüğünü kapsadığını kabul etmiştir. Mahkeme, genel sağlık

54 Anayasa md. 17. "Herkes yaşama, maddi ve manevi varlı̆̆ını koruma ve geliştirme hakkına sahiptir."

55 McCann v. Birleşik Krallık, A. 324 (1995); 21 EHRR 97 para 147 BD.

56 1998-III; 27 EHRR 212.

57 Bkz., Harris/O’Boyle/Bates/Buckley, s. 44.

58 Bu konudaki doktriner tartışma için bkz., Üzeltürk Tahmazoğlu, Sultan (2012) Anayasa Hukuku Açısından Sağlık Hakkı, İstanbul, Legal Yayınevi, s. 11-15.

59

2001-IV; 35 EHRR 731 BD. 
hizmeti sunmamaktan ötürü bireyin yaşamını devletin riske atması durumlarında 2. madde sorumluluğunu benimsemiştir. Ancak Mahkeme, ilgili davanın olguları bakımından söz konusu sorumluluğun doğmadığına karar vermiştir. ${ }^{60}$ İdeal anlamda devletlerin egemenlik alanındaki herkese sunması gereken yaşam kurtarıcı sağlık hizmetlerine ilişkin yükümlülügün, devletlerin mali kaygılarına bağlı olduğu kaydedilmiştir. Temel ve acil sağlık hizmetlerinin bir kamu hizmeti olarak sunulması, ilgili 2. madde açısından beklenmekle birlikte, daha kapsamlı bir sağlık hizmeti sunma yükümlülüğü, $\mathrm{AB}$ ulusal mevzuatlarında görüldüğü üzere 'mevcut kaynaklarla' sinırlandırılmıştır. ${ }^{61}$

$\mathrm{Bu}$ bağlamda dikkat çekici bir başka karar ise, AİHM yargılamasına konu olan Oyal v. Türkiye davasında verilmiştir. ${ }^{62}$ Mahkeme, Sözleşme’nin (AİHS) 2. maddesinin yalnızca devlet görevlilerinin haksız güç kullanımı sonucunda meydana gelen ölümleri kapsamadığını, ayrıca maddenin birinci paragrafının birinci cümlesinde devletlerin kendi yetki alanlarında bulunanların yaşamını koruma amacına uygun biçimde 'pozitif yükümlülüğünü’ ortaya koyduğunu vurgulamıştır. Bu ilkelerin, halk sağlığı alanına da uygulanabilir nitelikte olduğu kabul edilmiştir. $\mathrm{Bu}$ nedenle söz konusu 'pozitif yükümlülükler', devletin kamu veya özel hastanelerde hastaların yaşamının korunması için gerekli önlemleri almaya zorunlu kılan düzenlemeler yapmasını gerektirmektedir. ${ }^{63}$

60 Bkz., Harris/O'Boyle/Bates/Buckley, s. 49.

61 Bkz., Harris/O’Boyle/Bates/Buckley, s. 49.

62 Davanın ayrıntısı şöyledir; Söz konusu dava, erken doğumda kan nakliyle HIV virüsü enfekte edilen bir hastaya yaşaması için tam ve ücretsiz tıbbi teminat sağlanamamasıyla ilgilidir. Başvuranlar, devlet makamlarının HIV'in kan nakli yoluyla yayılmasını önleyecek önlemler almadığından ve etkili bir soruşturma yürütmediğinden şikayetçi olmuşlardır. Devletin 'yaşam hakkını koruma' sorumluluğu kapsamındaki 'pozitif yükümlülüğünü' yerine getirmediği ve suç duyurularına ilişkin olarak etkili bir soruşturma yürütmediği iddia edilmiştir. Başvuranlar, Sözleşme'nin 2. maddesinin sadece kurbanın ölümüyle sonuçlanan olayları değil, aynı zamanda kurbanın hayatını tehdit eden, ciddi bir hasara maruz kaldığı olayları da kapsadığını ileri sürmüştür.

63 Oyal / Türkiye Davası, AİHM, 4864/05 Başvuru no, http://hudoc.echr.coe.int/eng?i=001162088, s.e.t. 24.05.2020. 


\section{SAĞLIK HAKKININ KORUNMASI VE SAĞLIK HİZMETLERİNE ERİ̧̧IM HAKKI}

'Insan Hakları Evrensel Bildirgesi' md. 25/1'de yer alan tanımlaması esas alındığında temelde 'insanın iyilik haline ulaşmasını hedeflemiş' olmasından ötürü 'sağlık hakkının' insan hakları ile bir 'amaçsal birlikteliğe' sahip olduğu ifade edilebilir. ${ }^{64}$ Kapsamı itibariyle sağlıklı yaşamdan sağlık hizmetlerinin sunumuna varıncaya kadar oldukça geniş bir hak çerçevesi ile tanımlanabilecek olan 'sağlık hakkı' dinamik bir içerime sahip bulunmaktadır. ${ }^{65}$ Küreselleşen dünyada bu dinamik değişkenleri var eden modern yaşam, ilgili alanı hızlı bir transformasyona uğratmaktadır.

Evrensel Bildirgede yer alan, 'beslenme, barınma, çalışma ve eğitim hakkı' gibi haklar ile 'sağlık hakkı' yakından ilişkilidir. Bunlar ve diğer haklar sağlık hakkının ayrılmaz bileşenlerini oluşturmaktadır. ${ }^{66} \mathrm{Bu}$ çerçevede sağlık hakkı, birçok sağlık hizmeti hakkını içermekle birlikte, 'güvenli içme suyu, yeterli sanitasyon ve sağlıkla ilgili bilgilere erişim’ gibi sağlığın temel belirleyicilerini kapsayarak sağlık hizmetinin ötesine geçmektedir. $\mathrm{Bu}$ hak, ayrımcllı ve istemsiz tıbbi tedaviye (involuntary medical treatment) maruz kalmama hakkı gibi özgürlükleri de içermektedir. Ayrıca birinci basamak temel sağlık hizmeti hakkı gibi yetkileri de kapsamına almaktadır. Bu hak, çocuk sağlığı, anne sağlığı ve temel ilaçlara erişim de dahil olmak üzere birçok unsuru kapsamaktadır. ${ }^{67}$ Böylesine kapsamlı bir içerime sahip olan sağlık hakkı, insan haklarının telosuna uygunluk arz eder biçimde bireyin devlet ile olan asimetrik ilişkisinde karşı tarafı yükümlendirici hak temelli bir 'bireysel talep meşruiyeti' yaratmaktadır.

Böylece 'sağlık hakkı' ile insan hakları arasındaki ilişkinin, her biri bir diğeri ile içsel bir bağıntısı bulunan ve her birinin önemli pratik sonuçları olan

\footnotetext{
64 Alptekin, Kamil (2004) "Sağlık Hakkı ve İnsan Hakları Üzerine Bir Değerlendirme”, T Klin J Med Ethics, Law and History, S: 12, s. 137-138.

65 Bkz., Bulut, s. 207-209.

66 Committee on Economic, Social and Cultural Rights, "General Comment No. 14."

67 Hunt, Paul (2006) "The Human Right to the Highest Attainable Standard of Health: New Opportunities and Challenges", Transactions of the Royal Society of Tropical Medicine and Hygiene, Vol: 100, p. 604.
} 
kavramsal bir çerçeveye sahip olduğunu söyleyebiliriz. Bu çerçeve, birbiri ile ilişkilendirilebilir üç bağıntı düzlemi üzerinden açımlanabilir. Bunlardan ilki; 'sağlık politikalarının, programlarının ve uygulamalarının' insan hakları üzerindeki etkisini halk sağlığı bağlamında incelemektedir. Öncelikle sağlık politikaları ve uygulamalarının insan hakları üzerindeki olumlu ya da olumsuz etkisi halk sağlığı bağlamında devlet gücünün kullanımı çerçevesinde açıklanabilir. ${ }^{68}$ İkinci ilişkisellik düzeyi ise, negatif anlamda insan hakları ihlallerinin 'sağlık hakkı' üzerindeki etkileridir. Bu meyanda örneğin; 'işkence ve kötü muamele'; 'ceza ve tutukevlerinde insani yaşam koşullarının bulunmaması'; 'yargısız infaz ve kayıp olayları' ile kişisel sağlık durumu arasında ilişki bulunmaktadır. ${ }^{69}$ Üçüncü ilişkisellik düzeyi ise; 'sağlık hakkı' ile 'insan hakları' arasındaki kopmaz bağıntıdır. İnsan haklarının korunması ve geliştirilmesi, bizatihi sağlığın korunması ve geliştirilmesiyle bağlantılıdır. $\mathrm{Bu}$ kapsamda en yaygın kabul gören analiz, kişilerin sosyo-ekonomik durumlarına ilişkin tespittir. Sosyo-ekonomik durum açısından bireyin varsıllığı ile sağlık durumunun iyi olması arasında pozitif bir ilişki tespit edilmiştir. $^{70}$

İnsan haklarının bütünlüğü fikrine bağlı biçimde devletler, yurttaşlarının mümkün olan en yüksek fiziksel ve zihinsel sağlık standartlarından yararlanabilmesi için gerekli adımları atmak durumundadır. $\mathrm{Bu}$, bir yandan güvenli olmayan içme suyu veya beslenme gibi dış tehditlerden korunmayı; sağlıklı çalışma koşullarını; sağlıklı bir yaşam ortamını ${ }^{71}$

68 Mann, Jonathan M./Gostin, Lawrence/Gruskin, Sofia/Brennan, Troyen/Lazzarini, Zita/Fineberg, Harvey V. (1994) "Health and Human Rights", Health and Human Rights, Vol: 1, N: 1, p. 13-15.

Bkz., 'Sağlıkta insan haklarının sağlık sonuçlarını iyileştirme çabalarında 'katma değere' düşürülmesi sadece stratejik bir hata değildir çünkü sağlıkla ilgili haklar daha sonra anlamlı demokrasi ve sosyal adalet için daha geniş mücadelelerle ilgisiz olarak algılanan 'sağlık' içinde silolanmıştır. Bu aynı zamanda epistemik bir hatadır çünkü hak savunuculuğunun nihai hedefi, sıradan ve çeşitli insanların haysiyetle yaşamalarını sağlamaktır- ki bu sağlıklı yaşam koşullarını içerir.' Yamin, Alicia Ely (2019) "Struggles for Human Rights in Health in an Age of Neoliberalism: From Civil Disobedience to Epistemic Disobedience”, Journal of Human Rights Practice, Vol: 11, p. 365-366. 
sağlayacak önlemleri ve sağlık eğitimini gerekli kılmaktadır. Öte yandan devletlerin, özellikle savunmasız grupların gereksinimlerini karşılamak üzere yeterli kalitede sağlık hizmetlerinin erişilebilirliğini sağlaması gerekmektedir. ${ }^{72}$ Bunu temin adına; sağlık hakkının özünün belirlenmesine yönelik olarak Dünya Sağlık Örgütü (WHO), 'Health for All' (Herkes İçin Sağlık) adlı bir girişim başlatmıştır. WHO, söz konusu girişim/kampanya kapsamında, birinci basamak sağlık bakımına ilişkin temel unsurları yeniden sayarak hakkın öz/çekirdek içeriğine dair standartlarını yenilemiştir. ${ }^{73}$ Söz konusu unsurlar şöyle sıralanmıştır; "ülkedeki herkesin temel sağlık hizmetlerine ve birinci kademe sevk tesislerine hazır erişime sahip olması; güvenli içme suyu ve sanitasyonun herkes tarafından kullanılabilir olması; bütün insanların yeterince beslenmesinin sağlanması; bütün çocuklara, çocukluğun başlıca bulaşıcı hastalıklarına karşı bağışıklık kazandırılması; bulaşıcı hastalıklarla mücadele edilmesi; temel ilaçların herkes için açık olması." ${ }^{\text {"74 }}$

'Ulaşılabilir en yüksek sağlık standardına' (the highest attainable standard of health) sahip olma hakk1, ${ }^{75}$ belirli bir normatif derinlikte ve yapıc1 politikalarla geliştirilebilir. Bu hak, sağlık politikalarının savunmasız ve dezavantajlı kişilere özel önem verilmesini, toplumsal katılımın artırılmasını, sağlık sistemlerinin güçlendirmesini vd. sağlamaya katkı sağlayabilecektir. ${ }^{76}$ Bu noktada belirtilmelidir ki, 'Ulaşılabilir en yüksek sağlık standardı hakkının' temelinde sağlık hizmetlerini sağlı̆̆ın temel belirleyicilerini kapsayan, ulusal

72 Gevers, Sjef (2004) "The Right to Health Care", European Journal of Health Law, Vol: 11, N: 1, Netherlands, p. 29.

73 Ertan (2012), s. 118.

74 WHO (1981) “Global Strategy for Health for All by the Year 2000”, Geneva, p. 53.

$75 \mathrm{Bu}$ çerçevede olmak üzere 'ulaşılabilir en yüksek sağlık standardının' ölçülebileceği parametreler şu şekilde sıralanabilir. Bunların, 'morbidite, mortalite ve özürlülük'; 'çocukların büyüme ve gelişme dönemlerinde alınan pozitif sağlık önlemleri'; ve yetişkinlerde ise 'demografik değişkenler, üreme sağlığı, sağlıklı yaşam tarzları, davranış ve uygulama’ kriterleri ile ölçülebildiğini kaydedebiliriz. Buradaki odak noktası bireyleri ve popülasyonları etkileyen sağlık sonuçlarıdır. Bkz., Gruskin, Sofia/ Tarantola, Daniel (2005) "Health and Human Rights", Perspectives on Health and Human Rights, (ed. Sofia Gruskin; Michael A. Grodin; George J. Annas; Stephen P. Marks), New York and London, p. 27.

76 Hunt (2006), p. 604. 
ve yerel önceliklere yanıt veren ve herkese açık olan etkili ve entegre bir sağlık sistemi yatmaktadır. Güçlü sağlık sisteminin sağlıklı ve eşitlikçi bir toplumun vazgeçilmez unsuru olduğuna ilişkin yükselen bir kabul bulunmaktadır. Böyle bir sağlık sistemi olmadan, ulaşılabilir en yüksek sağlık standardına sahip olma hakkının gerçekleştirilmesi pek mümkün görünmemektedir. Herhangi bir toplumsal yapıda etkin bir sağlık sistemi, adil bir yargı sistemi veya demokratik siyasal sistemden daha az önemde olmayan çekirdek sosyal kurumdur. ${ }^{77}$ Temelde, 'ulaşılabilir en yüksek sağlık standardına sahip olma hakkı' küresel olarak meşrulaştırılmış standartlardan oluşmaktadır. Söz konusu standartlara aykırılıklar birtakım yasal yükümlülükler doğurmakta ve bu yükümlülükler etkin hesap verebilirlik mekanizmalarını gerekli kılmaktadır. 'Standartlar, yükümlülükler ve hesap verebilirlikten' oluşan bu üç boyutun bileşik etkisi, savunmasız bireylerin ve dezavantajlı toplulukların güçlendirilmesidir. ${ }^{78}$

$\mathrm{Bu}$ çerçevede 'Ekonomik, Sosyal ve Kültürel Haklar Komitesinin', yayınlamış olduğu 'Genel Yorum'da taraf devletlerin 'sağlık hakkı' konusunda özel yasal yükümlülükleri şu şekilde sıralanmıştır: Buna göre 'taraf devletler, sağlık hakkı ile ilgili hizmetlere bütün kişilerin (mahkumlar, tutuklular, azınlıklar, mülteciler ve hukuk dışı göçmenler de dâhil) eşit ulaşımını engelleyen ve sınırlayan girişimlerden kaçınmalıdırlar; devlet politikası olarak ayrımcılık yapmamalıdırlar; geleneksel tıbbi tedavi yöntemlerini engellememelidirler; ayrıca taraf devletler, havanın, suyun, toprağın ve benzerlerinin hukuk dışı kirletilmesinden de kaçınmalıdırlar’. ${ }^{79}$

Netice itibariyle, sağlık hakkı kapsamında bir insan hakkı ${ }^{80}$ olarak tanımlanabilecek olan sağlık hizmetlerinin, yerinde ve erişilebilir bir kamu

77 Hunt, Paul (2008) Report of the Special Rapporteur on "The Right of Everyone to The Enjoyment of The Highest Attainable Standard of Physical and Mental Health", General Assembly, UN Doc A/HRC/7/11.

78 Hunt (2006), p. 604. Philosophy, Vol: 30, N: 6, p. 655. İnsan hakkı olarak sağlık hakkının değerlendirilmesine ilişkin doktriner tartışma için bkz., Üzeltürk Tahmazoğlu, s. 15-17. 'Bu argüman şu şekilde 
hizmeti olarak sunulabilmesi güçlü bir altyapıyı ve etkin bir sağlık sistemini gerekli kılmaktadır. Söz konusu kamu hizmeti, tekil anlamda bireylerin yurttaşlık hukuku çerçevesinde sağlık hizmeti alabileceği bir güvence mekanizmasını yani 'sosyal güvenlik hakkını' gerektirmektedir. Buna önleyici sağlık tedbirlerinin alınmasına ilişkin kurumsal sağlık hizmetleri de dahil edilmelidir. Bütün bu kamusal sorumluluğun devlet tarafından yeterli düzeyde ifa edilebilmesinin belirli bir bütçesel maliyet getirdiği aşikârdır. Sonuçta, sağlık hizmetlerine erişimin kamusal sorumluluk doğuran bir hak olarak tanımlanması, bütçesel maliyet hesabı gözetilmeksizin devletin pozitif yükümlülüğünü ifa etme zorunluluğunu beraberinde getirmektedir. ${ }^{81}$

\section{PANDEMI DÖNEMİNDE SAĞLIK HAKKININ SOSYAL DİNAMİĞ $\dot{I}$}

Dünya tarihinde insanlık, uzunca yıllar kamu sağlığını tehdit eden Covid-19 pandemisine benzer çok sayıda salgının yıkıcı ve/ya ölümcül etkisine maruz kalmıştır. Bütün dünyayı etkisi altına alan ölümcül pandemi bilançoları, kuşkusuz insanlık tarihi açısından esaslı dönüştürücü kırılmaları da beraberinde getirmiştir. Çağ kuşaklarını hem bedensel ve zihinsel hem de sosyal anlamda enfekte eden pandemiler, sonraki dönemler açısından ciddi düşünsel dönüşümlere, paradigmatik kırılmalara ve sosyo-kültürel değişimlere yol açmıştır.

Bu yönüyle, köklü dönüşümlere yol açan pandemi krizleri, bütünlüklü biçimde değerlendirmeye konu edilmek durumundadır. Tarihte kitleselleşen ölümcül salgınlar gibi halen yıkıcı etkileri sürmekte olan Covid-19 pandemisi

gerekçelendirilmiştir: iyi sağlık hizmetini neyin oluşturduğuna dair ortak bir anlayış olmaması, Hastaların sağlık tercihlerinin farklılık göstermesi, tıp kültürü ve uygulama standartlarının bir yerden diğerine farklılık göstermesi; mevcut hizmetlerin ve faydaların yeni teknolojilerin kullanılmaya başlanmasıyla sık sık değişmesi; ve doktorların hastalarının neye ihtiyacı olduğuna dair bağımsız klinik kararlar verebilmesi iyi sağlık hizmetini neyin oluşturduğuna dair ortak anlayışın olmadığını göstermektedir.

81 De Campos, Thana Cristina (2017) "The Human Right to Health and Its Corresponding Responsibilities", In The Global Health Crisis: Ethical Responsibilities, Cambridge University Press, p. 70. 
de etkilediği coğrafyalarda sosyal ve ekonomik yapıları ağır tahribata uğratmıştır. Pandemi krizlerinin değerlendirmeye alınması gereken esaslı boyutlarından birisini özellikle sosyal yapı dinamiği oluşturmaktadır. O yüzden bu başlık altında 'sağlık hakkı' temelinde Covid-19 pandemisinin sosyal dinamik üzerindeki etkileri üzerinde durulacaktır. Söz konusu sosyal dinamikler, bütün boyutları ile toplumsal yapıda farklı konum ve statüdeki insanlar üzerindeki etkilerine bağlı biçimde sağlık hakkını farklı açılardan etki altına almaktadır. ${ }^{82}$

Alicia Ely Yamin, 'sağlık hakkı fikrini ciddiye almanın' adil bir sağlık sistemini gerekli kıldığını kaydetmiştir. Sağlığı bir hak olarak tanımlamanın, 'fırsat eşitliğini' ve/ya 'yeteneklerin adil dağılımını' sağlamak için toplumdaki kurumların adaletli biçimde düzenlenmesini gerektirdiğini öne sürmüştür. Ona göre bir hak alanı olarak tanımlanan 'sağlık' yapılandırılan sağlık sistemleri üzerinden toplumun farklı kesimlerini birbirine bağlayan veya dışlayan, insanların yaşam şanslarını ve topluma tam olarak katılma yeteneğini tanımlayan 'çekirdek sosyal yapı' olarak işlev görmektedir. ${ }^{83}$ Hak ve adalet temelinde talep edilebilir bir hizmet olarak tasavvur edildiğinde sağllk ve beraberinde sağlık sistemlerinin, onurlu yaşam için firsatları etkileyen sosyal ve güç ilişkilerini nasıl yansıttığı ortaya çıkmaktadır. ${ }^{84}$ Bu yönüyle sağlık hakkı, bir sosyal değişken olarak varlık göstermektedir.

Sağlık hakkı ile ilgili en önemli yükümlülüklerden birisi de ayrımcılı̆̆ 1 önlenmesidir. Söz konusu yükümlülük, doğrudan sosyal dinamiğe ilişkin bir boyuta tekabül etmektedir. Öyle ki 'cinsiyet, 1rk, etnik köken ve diğer faktörler' temelindeki ayrımcılık sağlığın sosyal bir belirleyicisi olarak karşımıza çıkmaktadır. Zira sosyal eşitsizlikler ve dışlanma sağlık sonuçlarını biçimlendirmekte ve marjinal grupların taşıdığ 1 hastalık yükünün artmasına

82 Barry, Brian (2017) Sosyal Adalet Neden Önemlidir (Çeviren: Ebru Kılıç), İstanbul, Koç Üniversitesi Yayınları, s. 81.

Yamin, Alicia Ely (2017) "Taking the Right to Health Seriously: Implications for Health Systems, Courts, and Achieving Universal Health Coverage", Human Rights Quarterly, Vol: 39, N: 2, p. 351; Freedman, Lynn P. (2005) “Achieving the MDGs: Health Systems as Core Social Institutions”, Development, 2005, https://www.publichealth.columbia.edu /sites/default/files/pdf/freedman_achieving_mdgs.pdf, s.e.t. 20.06.2020.

Yamin (2017), p. 367. 
katkıda bulunmaktadır. Buna ek olarak, bazı endemik ya da pandemik niteliğe bürünen birtakım sağlık durumları da (AIDS, HIV, Covid-19 gibi) 'bileşik ayrımcılık biçimlerine' maruz kalmayı içerebilir ve var olan eşitsizlik durumlarını da derinleştirebilir. ${ }^{85}$

Eşitsizliklerin zarar verici etkilerine örnek olarak, yeterli düzeyde sağlık sistemleri altyapısına sahip olmayan Batı Afrika ülkelerinde yaşanan Ebola salgını verilebilir. Bu ve başkaca salgın hastalıklardan öğrenilen derslerden birisi, 19. yüzyıldan beri birçok salgın hastalığın kökeninde sosyal hastalık (social diseases) olduğunu vurgulayan sosyal tıbbın önemi olmuştur. $\mathrm{Bu}$ nedenle, sağlığın sosyal belirleyicilerinin ve salgın hastalıkların ortaya çıktığı sosyal bağlamın uygun biçimde ele alınması gerekmektedir. ${ }^{86}$ Nitekim insanların sosyo-ekonomik koşulları yaşamları boyunca onları güçlü bir şekilde etkilemektedir. Bu nedenle sağlık politikası, sağlı̆̆ın sosyo-ekonomik belirleyicileriyle bağlantılı olmak durumundadır. Zira herhangi bir bireyin sosyal ve ekonomik koşullarının yetersizliği, yaşamı boyunca onun sağlığını etkilemektedir. Bu noktada sağlığın sosyal belirleyicileri, insanların 'doğduğu, büyüdüğü, yaşadığı, çalıştığı ve yaşlandığı koşullar' ile 'günlük yaşam koşullarını' biçimlendiren daha geniş güçler ile ekonomik, sosyo-politik ve politik sistemler bütünü olarak karşımıza çıkmaktadır. ${ }^{87}$

Bütün türleri ile kamusal bir hizmet olarak sunulan sosyal haklara erişim konusundaki 'eşitlik', yalnızca 'bölüşüm adaletini' temin edici bir faktör olarak işlev görmemektedir. Kaynaklara erişim noktasındaki 'paylaşım adaleti' üzerinden de sosyal haklar olarak sınıflanan 'eğitim ve sağlık hakkı ile sosyal güvenlik imkanları' gibi genel sosyal haklar Marshall'ın da vurguladığı üzere, işçileri de kapsamına almak suretiyle yurttaşlı̆̆ın genişletilmesine imkân

85 Pras, Dainius (2015) "Report of the Special Rapporteur on The Right of Everyone to The Enjoyment of the Highest Attainable Standard of Physical and Mental Health", General Assembly, UN Doc A/HRC/29/33; Hunt, Paul (2003) "Report of the Special Rapporteur," submitted in accordance with Commission resolution, 2002/31 E/CN.4/2003/58 13.

Pras (2015).

WHO (2008) "Closing The Gap In A Generation Health Equity Through Action On The Social Determinants Of Health," Geneva,

https://apps.who.int/iris/bitstream/handle/10665/69832/WHO_IER_CSDH_08.1_eng.pdf;s equence $=1$, s.e.t. 19.06 .2020 . 
sağlayacaktır. Nitekim sosyal hakların bu amaç doğrultusunda ve eşitlik temelinde kamusal hizmet olarak erişime açılması, birçok ülkede ${ }^{88}$ işçi sınıfının ulusal kültürle bütünleşmesine katkı sağlamıştır. ${ }^{89}$ Böylece sosyal haklara erişim noktasındaki eşitlikçi ve katılımcı yaklaşım sınıflar arasındaki sosyal bütünleşmeyi mümkün kılacak bir sosyolojik bağ yaratacaktır. Aksi durumda sosyal haklara erişim konusundaki sınıfsal mesafe, ulusal bütünlüğü ve bütünleşmeyi riske atan olumsuz bir etken olarak varlık bulacaktır.

Sosyal bünyeyi tahrip eden 'mesafe politikalarının' yanı sıra, küresel ekonomik dinamikleri ve ulusal ekonomik düzenleri tehdit eden pandemi krizi, netice olarak yine kırılgan grupları (özellikle yoksul kesimleri) yaşamsal bir darboğaza sürüklemektedir. Nitekim Covid-19 pandemisinin hem küresel ölçekte ekonomik büyümeyi bastırması hem kısa vadede sürdürülebilir kalkınmayı olumsuz etkilemesi kaçınılmaz biçimde yoksulluğun giderek daha da derinleşmesine yol açacaktır. Pandeminin yol açtığı ekonomik durgunluk, daha düşük gelir, daha az ücretli çalışma saatleri veya doğrudan işsizlik şeklinde birçok insanın istihdamını tehlikeye sokma riskini taşımaktadır. ${ }^{90}$

$\mathrm{Bu}$ çerçevede pandemi yoksulluk sınırında yaşayan insanlar, yaşlılar, engelli kişiler, gençler ve yerli halklar dahil olmak üzere nüfusları etkilemeye devam etmektedir. Erken kanıtlar, virüsün sağlık ve ekonomik etkilerinin yoksul insanlar tarafından orantısız bir şekilde karşılandığını göstermektedir. Örneğin, evsiz insanlar, virüs tehlikesine oldukça açıktırlar. Mülteciler, göçmenler veya yerinden edilmiş kişiler de daha az istihdam firsatı, artan yabancı düşmanlığı vb. nedeniyle pandemi döneminde orantısız bir şekilde zarar görmektedir. Doğru politikalar geliştirilmediği takdirde, Covid-19

88 Bu bağlamda ünlü İngiliz tarihçi E. P. Thompson'ın İngiliz işçi sınıfının oluşumuna dair klasik yapıtı ilgi çekici bir çözümlemeye yer vermektedir. Bkz., Thompson, Edward Palmer (2015) İngiliz İşçi Sınıfının Oluşumu (Çeviren: Uygur Kocabaşoğlu), 4. Baskı, İstanbul, Birikim Kitapları, s. 547 vd.

Kymlicka, Will (2020) Çokkültürlü Yurttaşlık (Çeviren: Abdullah Yılmaz), 3. Basım, İstanbul, Ayrıntı Yayınları, s. 300.

World Economic Situation And Prospects: Briefing No. 136 (2020) "COVID-19: Disrupting Lives, Economies and Societies", https://www.un.org/development/desa/dpad/publication/world-economic-situation-andprospects-april-2020-briefing-no-136/, s.e.t. 19.06.2020. 
salgınının yarattı̆̆ı sosyal kriz, orta ve uzun vadede eşitsizlik, dışlanma, ayrımcılık ve küresel işsizliği de artırabilir. ${ }^{91} \mathrm{Bu}$ noktada ifade edilmelidir ki Covid-19 krizinin, bizatihi bireyin ruh sağlığı ve davranışları ile sosyal tutumları üzerindeki olumsuz etkisi kaçınılmaz biçimde sosyal uyumu (social cohesion) tehdit etmektedir. Nitekim bu kapsamda olmak üzere başlangıçta, virüsün menşei ve yayılmasından 'sorumlu' tutulan bazı sosyal grupların ya da ülke vatandaşlarının damgalandığı görülmüştür. Hatta damgalanarak ötekileştirilen bazı sosyal gruplara yönelik birtakım şiddet olayları ortaya çıkmıştır. ${ }^{92}$

Neoliberal kapitalizmin merkezi olan $\mathrm{ABD}$, bu türden sosyal sorunların pandemi krizi ile birlikte daha da derinleştiği bir ülke görünümü vermektedir. Öyle ki sosyal bir sorun olarak ABD'deki gelir eşitsizliği, Covid-19 krizi ile birlikte yoksullar ile zenginler arasındaki sosyo-ekonomik mesafeyi daha da derinleştirme durumu yaratmıştır. Gelir düzeyi düşük olan emekçilerin, kısmen evden çalışabilme olasılıklarının daha zayıf olmasından ötürü, gelir azaltma ve iş kaybı yaşama ihtimali daha da yükselmiştir. Çalışmalarının doğası gereği virüse maruz kalma riski daha yüksek olanlar 'temel işçiler' (essential workers) olarak tanımlanmıştır. Fiziksel ve ekonomik refahlarına ilişkin söz konusu risklere ilaveten düşük gelirli çalışanların iyi sağlık hizmetlerine erişme olasılıkları ve de bu nedenle Covid-19 testi yaptırabilmeleri ve tedavi edilmeleri oldukça düşük bir ihtimal olarak karşımıza çıkmaktadır. ${ }^{93}$ Halbuki özellikle acil sağlık durumlarında mali koşulların yarattığı imkansızlıkların, kişileri temel/koruyucu sağlık hizmetinden mahrum birakan sosyo-politik ve sosyo-ekonomik pratiklerin insan haklarına aykırılığını ifade edebiliriz.

91 United Nations- Department of Economic and Social Affairs, "Everyone Included: Social Impact of COVID-19", https://www.un.org/development/desa/dspd/everyone-includedcovid-19.html, s.e.t. 19.06.2020.

92 United Nations (2020a) "Shared Responsibility, Global Solidarity: Responding to the Socioeconomic Impacts of COVID-19”, p. 11.

93 Davidai, Shai/Day, Martin V/Goya-Tocchetto, Daniela/Hauser, Oliver P./Jachimowicz, Jon M./ Usman, Mirza (2020) "COVID-19 Provides a Rare Opportunity to Create a Stronger, More Equitable Society”, p. 2. 
Özellikle sağlık acil durumlarının ortaya çıkardığı krizin 'eşitsizlik' temelinde bir insan hakları sorunu yaratabileceğine dikkat çeken Uluslararası Af Örgütü, bu tür durumlarda tüm hükümetlerin ve diğer aktörlerin salgınla mücadele kapsamında aldıkları tedbirlerde insan hakları perspektifinin merkeze yerleştirilmesini öngörmüştür. Örgüt, ulusların Covid-19 salgınına verdikleri karşılıkların uluslararası insan hakları hukuku ve standartlarına uygun olması, ötekileştirilen grupların ve insanların ihtiyaçlarının göz önünde bulundurulması, önlemlerle bağlantılı insan hakları risklerinin azaltılması ve bu risklerin ortadan kaldırılması konusunda çağrı yapmaktadır. Bu kriz, farklı dışlama biçimleri, eşitsizlik ve insan hakları ihlallerinin birbiriyle nasıl bağlantılı olduğunu ortaya koymaktadır. Hükümetlere, sağlık hakkının gereklerinin yerine getirilebilmesi noktasında yeterli bütçenin sağlandığı güçlü sağlık sistemlerine sahip olma imkanını da doğurmuştur. Herkesin yeterli yaşam standardından yararlanabilmesi için ayrımsız biçimde güçlü sosyal koruma mekanizmalarına sahip bir toplum öngörüsünü gerçekleştirecek bir toplum imkânı ortaya çıkmıştır. ${ }^{94}$

Virüsün mutasyona uğrayarak yayılım göstermeye devam ediyor olmasından kaynaklı biçimde farklı fazlar ve dalgalar halinde pandemi riskinin süreceğine ilişkin karamsar beklenti, sosyo-ekonomik yapıya ilişkin iyimser senaryoları baltalamaktadır. Bu noktada pandeminin seyrine ilişkin olumlu beklentileri boşa çıkarırcasına 'yaşam standartlarının kötüleşmesine, sosyal refahın azalmasına, eğitim başarısının düşmesine, zihinsel sağlı̆̆ın bozulmasına' bağlı biçimde giderek daha fazla sosyal ve sağlık gereksinimi ortaya çıkmaktadır. Tüm bu sosyal ve sağlık temelinde ortaya çıkan gereksinimlerin birtakım toplumsal eşitsizliklere ve sosyal parçalanmanın (social fragmentation) derinleşmesine yol açacağı görülmektedir. ${ }^{95}$

Sonuç olarak, sağlık hizmetleri alanında yaşanan sosyal eşitsizlik ağır bir sosyal bedel yaratmaktadır. Bu noktada özellikle 'gelir, eğitim, meslek, sosyal sınıf, cinsiyet ırk veya etnik köken gibi birtakım sosyal belirleyiciler ile

94 Amnesty International (2020a) “Europe At A Crossroads Dos And Don'ts For Authorities When Responding To The Covid-19 Pandemic", p. 12-13.

Jani, Anant (2020) "Preparing for COVID-19's Aftermath: Simple Steps To Address Social Determinants Of Health”, Journal of the Royal Society of Medicine, Vol: 113, N: 6, p. 205. 
birçok hastalığın görülme sıklığı ve ciddiyeti arasında bariz ve veriye dayalı biçimde kanıtlanmış bir ilişkisellik durumu söz konusudur. ${ }^{96}$

\section{PANDEMİ DÖNEMINNDE SAĞLIK HAKKININ KORUNMASI}

Küresel ölçekte 'halk sağlığını' tahrip edici bir pandemi yaratan Covid19 virüsünün sosyo-legal ve sosyo-politik anlamda en yıkıcı etkilerinden birisi de 'insan hakları siyaseti' alanında yaşanmıştır. Bu çerçevede 'yaşam hakkı' başta olmak üzere, 'sağlık hakkı; doğal çevre hakkı; güvenli ve sağlıklı koşullarda çalışma hakkı; ve sosyal güvenlik hakkı' gibi çok sayıdaki hak alanları bu viral tehditten etkilenmiştir. Bu noktada birden çok uluslararası örgüt ortaya çıkan hak ihlallerine ilişkin uyarıcı nitelikte çerçeve raporlar yayımlamıştır. $\mathrm{Bu}$ kapsamda olmak üzere Uluslararası Af Örgütü'nün yayınlamış olduğu 'Yedi Maddede Koronavirüsle Mücadelede İşlenen Hak İhlalleri' başlıklı rapor özellikle, 'sağlık hakkına' ilişkin ihlallerin varlığına dikkat çekmiştir.

Raporda virüsün çıkış noktası olan Çin'de ilk aşamada sağlık sisteminin büyük bir yük altında olmasından ötürü yeterli düzeyde sağlık hizmetine erişimin sağlanamadığı belirtilmiştir. ${ }^{97}$ Farklı kentlerden gelen sağlık çalışanları ile ülkenin klinik kapasitesi desteklenmiş olmasına rağmen, salgının ilk aşamasında Wuhan kentinde Covid-19 tarama ve tedavi talebi karşılanamamıştır. ${ }^{98}$ Virüsün hızlı küresel yayılımı karşısında başta Avrupa ülkeleri ve Amerika Birleşik Devletleri olmak üzere benzer 'ihlallerin' birçok ülkede varlık göstermiştir.

Kurumsal görüş olarak Örgüt, salgının kontrol altına alınması kadar, salgını engellemenin ve tedavi etmenin de önemli olduğunu vurgulamıştır. Bu

\footnotetext{
96 Nassif P., Luiza/Masterson, Thomas/Nikiforos, Michalis/Rios-avila, Fernando/Xavier, Laura (2020) "Pandemic of Inequality", Public Policy Brief Levy Economics Institute of Bard College No. 149, p. 4.

97 Amnesty International (2020b) "Explainer: Seven Ways The Coronavirus Affects Human Rights”, https:/www.amnesty.org/en/latest/news/2020/02/explainer-seven-ways-thecoronavirus-affects-human-rights/, s.e.t. 15.06.2020.

98 Wang, Zhicheng/Tang, Kun (2020) "Combating COVID-19: Health Equity Matters", Nature Medicine, Vol: 26, p. 460-462.
} 
noktada bireyin pandemik risk karşısında güvenceli kılınması açısından 'sağlık hakkı' alınan tüm tedbirlerin temel unsuru olarak kaydedilmiştir. ${ }^{99}$ Kapsamı itibariyle burada sağllk hakkının, 'onurlu bir yaşam sürmeye elverişli en yüksek ulaşılabilir sağlık standardından yararlanma hakki olarak kabul edilmesi gerekmektedir. 'İnsan onuruna yaraşırlık' ilkesi ile kayıtlanan söz konusu hakka erişim noktasında kişilerin eşitlik temelinde sosyo-ekonomik durumlarının herhangi bir kısıt yaratmaması icap etmektedir. ${ }^{100}$

Her ne kadar bulaş riski açısından pandemi, başlangıçta tüm bireyleri eşitleyen bir tehdit olarak ortaya çıkmış olsa da mücadele sürecinde 'sosyal statü, ekonomik durum, sınıfsal aidiyet ve ırk' gibi birtakım etkenler temelinde birçok eşitsizlik durumu varlık göstermiştir. O yüzden, salgının kontrol altına alınması konusundaki küresel çabaların sözü edilen 'eşitsizlik durumlarını' bertaraf edecek eşitlikçi bir strateji geliştirmesi, insan haklarının amaçsal gereği olarak kaydedilmelidir. Öyle ki pandemi ile mücadelenin başarısı, hak temelinde 'sağlık eşitliği ya da hakkaniyetini' dikkate alan sağlık hizmetleri politikası ile mümkün olabilecektir. ${ }^{101}$ Zira ayrımsız biçimde tümüyle toplumsal yalıtımın oluşturulabilmesinin imkansızlığı, pandemi riski karşısında tüm insanları eşitlemektedir.

Diğer yanda Avrupa Sosyal Haklar Komitesi de pandemi ile mücadele sürecinde doğabilecek 'sağlık hakkı' ihlallerine dikkat çekerek taraf devletlere somut birtakım öneriler getirmiştir. Komite, taraf devletlere pandemi ile mücadele sürecinde yürüttükleri politikalar, çıkardıkları yasalar ve diğer idari eylemlerinde sağlığın korunması hakkına en yüksek önceliği vermek durumunda olduklarını beyan etmiştir. Bu çerçevede devletlerin yeterli sayıda hastane yatağının, yoğun bakım ünitelerinin ve ekipmanlarının bulunmasını sağlamak da dahil olmak üzere pandemi döneminde hasta olanları tedavi

\footnotetext{
99 Amnesty International (2020b).

100 United Nations (2020b), “COVID-19 and Human Rights-We Are All In This Together”, p. 4.

101 Wang, Zhicheng/Tang, Kun, p. 458.
} 
etmek için gerekli tüm önlemleri almak durumunda olduğu noktasına dikkat çekilmiştir. $^{102}$

Pandemi ile mücadele sürecinde 'sağlık hakkını' korumak adına mevcut kaynakların azami ölçüde seferber edilmesinde kamu hastanelerinin yanı sıra özel hastaneler ve diğer sağlık merkezlerinin kamu kullanımına açılması öngörülmektedir. Somut biçimde bu kapsamda tanı, destekleyici bakım ve gelecekte Covid-19 için geliştirilen tüm aşı ve tedaviler dahil olmak üzere tıp etiğine saygıll, bilimsel ve tıbbi açıdan uygun, nitelikli sağlık ürünleri ve sağlık hizmetlerinin ayrım gözetilmeksizin herkes tarafından erişilebilir olması beklenmektedir. ${ }^{103}$

Eşit erişim hakkı çerçevesinde pandeminin sürdüğü dönemde kendini etkin bir şekilde koruma imkânı olmadığı için enfeksiyon riski daha fazla olan veya yeterli sağlık hizmetlerine erişimde engellerle karşılaşan grupların evsizler, göçmenler, mülteciler, ileri yaştakiler, engelliler, cezaevleri gibi farklı yerlerde özgürlüğünden yoksun bırakılan kişiler vb.- haklarını korumak için belirli tedbirler öngörülüp uygulanmalıdır. ${ }^{104}$

$\mathrm{Bu}$ çerçevede küresel sağlığın korunması noktasında önemli bir role sahip olan Dünya Bankası ${ }^{105}$ da sağlık hakkının korunması amacıyla pandemi ile mücadeleye ilişkin birtakım uygulamalar geliştirmiştir. Dünya Bankası’nın küresel sağlıktaki rolü, Bankanın piyasanın ve diğer kurumların güçlü yönlerini dengelemesi ve müşteri ülkelerdeki insanlara odaklanması gereken bütünsel, bütünleşik ve çok boyutlu bir görev olarak gördüğü daha iyi bir

102 European Committee of Social Rights, "Statement Of Interpretation On The Right To Protection Of Health In Times Of Pandemic", 21 April 2020, p. 3-4. https://rm.coe.int/statement-of-interpretation-on-the-right-to-protection-of-health-inti/16809e3640, s.e.t. 15.06 .2020 .

103 Amnesty International (2020a), p. 5.

104 Amnesty International (2020a), p. 6.

105 Dünya Bankası'nın sağlık politikasının odağının 1970'lerdeki nüfus kontrolünden evrilerek sağlık sistemlerinin geliştirilmesine doğru yöneldiğini söyleyebiliriz. Bkz. Tichenor, Marlee/Sridhar, Devi (2017) "Universal Health Coverage, Health Systems Strengthening and the World Bank", British Medical Journal (BMJ), Vol: 358, p. 1. 
kalkınma anlayışıyla gelişim göstermiştir. ${ }^{106}$ Pandemik risk piyasası yaratmak adına Dünya Bankası, pandemi hazırlığını 'küresel kamu malı' ilan ederken, küresel sağlık güvenliğini sağlamada daha merkezi bir konuma gelmiştir. Finansal bir aktör olarak Banka, küresel sağlık sorununa finansal bir çözüm sunmaya çalışmaktadır. Dünya Bankası sağlık sorunlarına ilişkin olarak piyasa temelli çözümlere özellikle vurgu yapmıştır. ${ }^{107}$

Dünya Bankası Covi-19'a ilişkin olarak yapmış olduğu raporlamalarda ise pandeminin benzeri görülmemiş zorluklar yaratan bir talep ve arz şoku yarattığını kaydetmiştir. Küresel ekonomik bozulmaya yol açan bu krizin özellikle düşük gelirli ülkelerin giderek küresel finans piyasalarının dışında kaldığını vurgulamıştır. Salgının sosyal ve ekonomik sonuçlarının savunmasız kişileri orantısız bir biçimde etkilediği tespit edilmiştir. Bulaşma riski, kentsel gecekondu sakinleri ile sosyal mesafeyi daha az uygulayabilenlerin yanı sıra, bunu yapmaya gücü yetmeyen piyasa tüccarları (market traders) gibi gruplar arasında daha yüksek olduğu belirtilmiştir. Bu noktada alınacak ekonomik tedbirlerin önceden var olan güvenlik açıklarının alevlenmesine yönelik olması ve geçim kaynakları tehdit altında olanların desteklenmesi gerektiği vurgulanmıştır. Halk sağlığına ilişkin olumsuz etkilerinin ötesinde Covid-19, insanların 'temel hizmetlere, gıdalara ve geçim kaynaklarına' erişimini bozarak sağlık, eğitim, beceri ve üretkenlikte zor kazanılmış insan sermayesi kazanımlarının yavaşlamasına veya tersine çevrilmesine yol açmaktadır. En yoksul ve en savunması hane halkı ve nüfus, özellikle ekonomik zorunluluktan sosyal mesafe kuralını uygulayamadığı veya gelire erişimi kaybettiği için daha fazla acı çekmektedir. ${ }^{108}$

Şüphesiz bu noktada pandemi krizinin ortaya çıkarmış olduğu en trajik tablolardan birisi, dünyanın küresel hegemonik gücü olan $\mathrm{ABD}^{109}$ kendisini

106 Ruger, Jennifer Prah (2005) “The Changing Role Of The WORLD BANK In Global Health", American Journal of Public Health, Vol: 95, N: 1, p. 69.

107 Stein, Felix/Sridhar, Devi (2017) "Health as a 'Global Public Good': Creating A Market For Pandemic Risk", British Medical Journal (BMJ), Vol: 358, p. 1.

108 World Bank (2020) "Protecting People And Economies: Integrated Policy Responses To Covid-19”, World Bank Group, p. 9-10.

109 ABD'nin sağlık hizmetleri alanında diğer ülkelerle karşılaştırma yapıldığında yapılan harcamanın yüksekliğine rağmen, yeterli bir sonucun elde edilememesine ilişkin dört 
göstermiştir. Neo-liberal kapitalizmin ikonik temsilcisi olan bu küresel gücün pandemi ile mücadele sürecindeki performansı, 'sağlık hakkı, sağlık sistemi ve sağlık hizmetleri' gibi konular üzerinden insan hakları siyasetine ve daha genelde siyasal sistemine dair sorgulamaları beraberinde getirmiştir. Oldukça yüksek maliyetli olan sağlık hizmetlerinden yararlanma ve bunun da öncesinde belirli bir gelir seviyesinin altında olmaktan kaynaklanan yetersiz/sağlıksız beslenmenin yol açtığı çaresizliklere bağlı biçimde salgın sürecinden en çok etkilenen kesim, etnik azınlıklar olmuştur. Sağlıksız beslenme oranının yüksek olduğu bu kırılgan gruplar açısından ülkenin sağlık sistemi etkin bir güvence mekanizması sunmamaktadır. ${ }^{110}$

Tam da bu noktada Türkiye, pandeminin yıkıcı etkisine maruz kalan Amerika ve birçok Avrupa ülkesi gibi ülkelerden pozitif ayrışmıştır. Zira bu çerçevede olmak üzere mali olanakları ölçüsünde devlete 'pozitif yükümlülükler' getiren sağlık hakkına yatırım noktasında Türkiye, özellikle son 15 yıllık süreçte 'sağlıkta reform politikaları' ile oldukça ciddi gelişmeler kaydetmiştir. Türkiye, sağlık hakkı kapsamında yapılacak olan yatırımları, politik önceliği olan stratejik bir alan olarak benimsenmiş ve sağlık hizmetlerinin iyileştirilmesi adına pek çok reformist adım atmıştır. Yapısal reformlara dayalı biçimde son yıllarda yürütülen sağlı politikalarının semeresi, pandemi döneminde kendisini net bir biçimde göstermiştir. Büyük

hipotez öne sürülmüştür. İlki, daha fazla sağlık hizmeti alınamamasına rağmen, bunun için daha fazla harcama yapılmasıdır. İkincisi, alınan sağlık hizmetinin niteliğine ilişkindir. Başka birçok ülkeden daha fazla görüntüleme cihazlarına (MR ve BT gibi) ve diyaliz makinesine sahip olmalarına rağmen sağlık göstergeleri (sağlık hizmeti) daha iyi değildir. Üçüncüsü, sağlık sisteminin 'eşitsizlik' temeli üzerine inşa edilmiş olmasıdır. Dördüncü hipotez ise, hasarı onarmak için daha fazla yatırım yapılsa bile, hasta bir toplum (sick society) yaratılmış bulunulmaktadır. Bu sistem daha fazla insanı sefalete ve çaresizliğe sürüklemektedir.' ABD’nin sağlık sistemine ilişkin tartışma konusunda bkz., Levins, Richard (2020) "Is Capitalism a Disease? The Crisis in U.S. Public Health", Brecht Forum in New York, Monthly Review, p. 16-18.

110 Amerika'da Covid-19 pandemisi kayıpları konusunda istatistiksel bilgi için bkz., USA CDC'nin (Centers For Disease Control and Prevention) 06 Temmuz 2020 tarihli verilere göre toplam vaka sayısı, 2.886.267 toplam ölüm sayısı 129.811 olarak kaydedilmiştir. https://www.cdc.gov/coronavirus/2019-ncov/cases-updates/cases-in-us.html, s.e.t. 06.07.2020. 
yatırım kapasitesinin var ettiği sağlık hizmeti altyapısı ile Türkiye, bugüne kadar pandeminin yıkıcı etkisi ile mücadele sürecini birçok ülke ile karşılaştırıldığında başarılı biçimde yürütmüştür. ${ }^{111}$

Sonuç olarak, Dünya Sağlık Örgütü, Uluslararası Af Örgütü ve Dünya Bankası gibi uluslararası örgütlerin kurumsal çabaları, küreselleşen dünyada eş düzeyde yıkıma maruz kalan insanlık için ölümcül tehditleri ve tehlikeleri öngörebilme ve yönetebilme noktasında yetersiz kalmaktadır. Bizatihi insan marifetiyle gerçekleşen doğanın tahrip edilmesi, ekolojik dengenin bozulması ve çevrenin kirletilmesi, ayrımsız tüm insanlığı bir uçuruma doğru sürükleyen küreselleşen bir tehdit yaratmaktadır. Dinamik biçimde giderek derinleşen hak kuramları, normatifleşen yeni hak dizgeleri ve kurumsallaşan insan hakları pratiği, ne yazık ki, küresel kamusal tehdide maruz kalan 'risk toplumunu ${ }^{112}$ güvenceli kılabilecek bir kudrete sahip değildir.

\section{SONUÇ YERINE}

Covid-19 pandemisi, küreselleşen dünyanın yaşam akış hızına ve momentine uygun biçimde oldukça kısa sürede tüm küreyi saran derin bir kriz alanı yaratmıştır. İnsanlık, 'akıllı teknolojik sistemler, ileri düzeyde rasyonalize edilmiş kurumsal örgütlenmeler, öngörebilme ölçekleri rafine edilmiş yüksek teknolojiler, incelikli istatistiksel hesaplamalar yapabilen hendeseler, toplumsallığ etkinlikle yönetme ve/ya yönlendirme kapasitesine sahip sosyal mühendislikler, dijital çağın gözetleme aygıtları ile donanmış yapay zekalar' ve buna benzer modern çağı muhkemleştiren birçok kurucu değeri âciz bırakan bir kriz ile karşı karşıya kalmıştır. Bu kriz, modern zamanda insanlığın kolektif hafızasında yer eden birçok anlam çerçevesini, bilgi hiyerarşisini ve değer dizgesini altüst eden bir zihinsel anafor yaratmıştır. 'Normale' dönüş umudu ile birlikte sönümleneceği şimdiden görülmekte olan bu anafor, yeni bir kamusal aklın yaratıcı zihinsel imkanlarının savurganlıkla

111 Ayrıntılı bilgi için bkz., Kılıç, Muharrem (2020) "Sağlıkta Şiddetin Önlenmesinin MedikoSosyal ve Yasal Dinamiği”, Rapor, Ankara, SETA Yayınları.

112 Beck'in başyapıtında tanımlamış olduğu toplumsal tipoloji için bkz., Beck, Ulrich (2016) Risk Toplumu, Başka Bir Modernliğe Doğru (Çeviren: Kâzım Özdoğan; Bülent Doğan), 2. Baskı, İstanbul İthaki Yayınları. 
heder edileceğine dair öngörüleri tahkim etmektedir. Bütün bu umut kırıcı öngörülere rağmen akademik akıl, insanlığı 'apansı' yakalayan pandemi krizinin yakıcı biçimde bize hatırlattıkları üzerine teemmülde bulunma sorumluluğunu taşımaktadır.

Bu kapsamda olmak üzere, bu krizin derinleşerek ağır insani bedellere yol açmasının önündeki en önemli mücadele aygıtı 'sağlık hizmetleri' olmuştur. Sağlık, bir sektörel alan ve hizmet birimi olmanın ötesinde yaşamsal bir insan hakkı olarak insanın 'onurlu yaşam' idealitesinin temel bileşenlerinden birisini teşkil etmektedir. Ayrımsız biçimde her bir insan tekinin hak öznesi olarak değerlendirildiği bir hak kategorisi olarak 'sağllk hakkı', çağ dinamikleri doğrultusunda insan hakları öğretisi ve uygulamasının 'sosyal adalet ilkesi' temelinde derinleşerek varlık bulmuştur. Hem haklar hiyerarşisi hem de hak sistematiği açısından birinci kuşak haklar ile sosyal haklar arasında ayrıştırıcı öğretisel yaklaşımlar olmakla birlikte, bütün hak kuşak ve türleri arasında akışkan bir diyalektikten söz edebiliriz.

Ancak sağlık, toplumun emek gücü değerinin bir parçası olması yönüyle sınıf mücadelesinde bir çekişme konusu olarak tanımlanmıştır. Bu niteliği ile sağlık, endüstrileşen sektörel alanda bir tüketim malı olarak yeniden varlık bulmuştur. Böylelikle bireye özgülenen bir sosyal hak olarak sağlik, neoliberal ekonominin dinamikleri doğrultusunda sektörleşmeyle birlikte bir anlamsal bulanıklığa maruz kalmıştır. Bu durumla birlikte 'sağlık', hastaneler, hasta bakım merkezleri ve ilaç şirketleri de dahil olmak üzere büyük bir endüstriyel sektör olarak kendisine yatırım yapılan bir 'meta' olarak algılanır hale gelmiştir. Hatta öyle ki sağlık hizmetleri, bu hizmete ihtiyacı olan ve hatta olmayan varsıl insanların müşteri oldukları büyük bir pazar olarak her geçen gün büyümektedir. ${ }^{113}$ Ancak tüm donanım, ekipman ve hizmetleri ile bir 'metaya' dönüşen 'sağlık endüstrisinin' pandemi sürecinde gereksinim duyulan acil sağlık hizmetlerinin sunumu noktasında yetersizliği ve yarattığı kısıtlar ortaya çıkmıştır.

'Sağlık endüstrisinin' kâr maksimizasyonuna dayalı motivasyonu ve etiko-jüridik değerleri teğet geçen iş potansiyeli, sağlık hakkına ilişkin

113 Levins, Richard (2020), p. 32. 
birtakım kuşkuları beraberinde getirmiştir. İlaç sanayisinden önleyici hekimlik uygulamalarına, tıbbi müdahalelerden sağlık turizmine kadar bütün unsurları ile sağlık hizmetinin endüstriyel bir ticari alana dönüşmesinin beraberinde getirdiği etik soruna dikkat çeken birçok eleştirel yaklaşım bulunmaktadır. Bu meyanda özellikle 'sağlığın gaspından' söz eden Ivan Illich'in radikal eleştirisi dikkat çekicidir. ${ }^{114}$ Özellikle neoliberal kapitalizmin mutlak egemenliğini sürdürdüğü ve sosyal adaletin dikkate alınmadığı ülkelerde sektörel dinamiklere teslim edilen 'sağlığın gaspı', pandemi ile mücadeleyi zaafa uğratan en büyük etken olarak varlık bulmuştur.

Özgün tarihsel dinamikleri çerçevesinde 'sosyal adalet ve sosyal devlet ilkesi' ile 'refah devleti' uygulamaları üzerinden biçimlenen sosyal hakların tanınması ile birlikte doğan kamusal maliyet, neoliberal ekonomi-politiğin üstlenmek istemediği bir durum yaratmıştır. Bu isteksizlik politikasının 'sağlık hakkı' bağlamında yol açtığı maduniyetler krizle mücadele sürecinde özellikle kırılgan gruplar üzerinde ölümcül bir risk doğurmuştur. Küresel piyasa ekonomisinin devlet dışı kurucu aktörleri ve dinamikleri tarafından sistematik bir yadsımaya maruz kalan sosyal haklar alanındaki yetersizlikler, pandemik krizin yıkım bilançosunu ağırlaştırmıştır.

Son yıllarda, gelirler karşısında sosyal ve sağlık harcamalardaki hızlı artış ile söz konusu harcamaları karşılamak adına zorunlu biçimde yapılan kesintilerin, sanayileşmiş ülkelerde bir finansman sorunu doğurmasından ötürü, 'refah devleti' uygulamalarının krizinden söz edilmektedir. ${ }^{115} \mathrm{Bu}$ meyanda 'refah devleti', bir kriz anlatısı üzerinden neoliberal devlet kuramcılarından Marksist yorumculara ve neomuhafazakarlara kadar farklı düşünsel eğilimlerin eleştirilerine maruz kalmıştır. ${ }^{116}$ Ancak siyasal felsefe ve devlet kuramı üzerinden yürütülen bütün bu eleştirellikleri paranteze alarak

114 Illich, kışkırtıcı bir söylemle bizatihi 'tıp kurumunun sağlık açısından büyük bir tehlikeye' dönüştügünü öne sürmüştür. Ona göre tıp alanındaki profesyonelliğe dayalı egemenliğin etkisi salgın boyutlarına ulaşmıştır. Düşünür bu yeni salgının adını 'iatrojenez' olarak belirlemiştir. Bkz., Illich, Ivan (2017) Sağlığın Gaspı (Çeviren: Süha Sertabiboğlu), 4. Basım, İstanbul, Ayrıntı Yayınları, s. 11.

115 Rosanvallon, s. 9.

116 Ayrıntılı bilgi için bkz., Dericiler Yücel, s. 81 vd. 
ifade edecek olursak, Pierre Rosanvallon'un da işaret ettiği üzere kriz dönemlerinde refah devleti krizin etkilerini hafifletme işlevi görmüştür. Özellikle kriz dönemlerinin sosyo-ekonomik etkilerini hafifletmek suretiyle, dünya ekonomisinin 'keskin duraklama sarmalına hapsolmasının' önüne geçmiştir. ${ }^{117}$ İçinde bulunmuş olduğumuz pandemi krizinin öngörülebilirlikten kısmen uzak olan sosyo-ekonomik sonuçlarının yaratacağı yıkıcı etkinin hafifletilebilmesi, ancak sosyal haklar temelinde yapılandırılan 'sosyal koruma mekanizmalarının’ etkin işlevselliği ile mümkün olabilecektir.

Covid-19 pandemisi ile sinırlı olmaksızın dünya tarihinde insanlığı tehdit eden tüm kitlesel salgınlar, insan yaşamına kasteden yıkıcı halk sağlı̆̆ sorunu olmanın ötesinde ağır sosyal ve ekonomik neticeler doğuran trajediler olarak tarihe geçmiştir. Bu yönüyle, yol açtığı yıkım tablosu açısından değerlendirildiğinde pandemiler yalnızca insan sağlı̆̆ açısından değil, sosyal yapı dinamikleri açısından da derinlemesine bir düşünümselliği gerekli kılmaktadır. Bu açıdan değerlendirildiğinde Covid-19 pandemisinin bulaş riski temelinde eşitlediği toplumsal sınıflar arasındaki mesafenin alınan sağlık hizmetlerinin yeterliliği ve kalitesi noktasında açıldığı görülmüştür. Pandemi süreci, bir takım sosyal belirleyiciler temelinde bazı kırılgan gruplara yönelik ayrımcılığın daha da derinleşmesine yol açmıştır. Ayrıca bazı ülke verileri dikkate alındığında pandeminin ölümcül etkisinin en çok maduniyet yaşayan toplumsal sınıflar üzerinde olduğunu göstermiştir.

Sonuç olarak küreselleşmenin bütün sosyo-ekonomik ve sosyo-kültürel taşıyıcı akslarını ve hedef ayırt etmeksizin global sistemin tüm güç merkezlerini can evinden vuran pandemi krizi, insan hakları siyaseti ve uygulamaları açısından ağır maduniyetler yaratan sistemsel aklın çöküşüne tanıklık etmiştir. Bu trajik tanıklığı sona erdirecek bir düşünsel ricate gereksinim duyulduğu aşikârdır. İnsanlık adına umudu yeşertebilmenin bir gereği olan bu ricat hali, sürdürülebilir bir düşünsel yoğunlaşmayı gerekli kılmaktadır. Bir bütün olarak sosyal haklar siyasetine dair düşünümselliğimiz bu fikri mesainin önemli ayaklarından birisi olarak karşımızda durmaktadır.

117 Rosanvallon, s. 9. 


\section{KAYNAKÇA}

Aktaş, Sururi (2018) Hayek'in Hukuk ve Adalet Teorisi, 2. Baskı, Ankara, Liberte Yayınları.

Algan, Bülent (2007) Ekonomik, Sosyal ve Kültürel Hakların Korunması, Ankara, Seçkin Yayınları.

Alptekin, Kamil (2004) "Sağlık Hakkı ve İnsan Hakları Üzerine Bir Değerlendirme”, T Klin J Med Ethics, Law and History, S: 12, s. 132139.

Amnesty International (2020a) "Europe At A Crossroads Dos And Don'ts For Authorities When Responding To The Covid-19 Pandemic".

Amnesty International (2020b) "Explainer: Seven Ways the Coronavirus Affects Human Rights".

Azarkan, Ezeli (2018) Uluslararası Hukukta Sağlık Hakkı, Ankara, Seçkin Yayıncilık.

Balcı Gökçeoğlu, Şebnem (2007) Tutunamayanlar ve Hukuk, Ankara, Dost Kitabevi Yayınları.

Barry, Brian (2017) Sosyal Adalet Neden Önemlidir (Çeviren: Ebru Kılıç), İstanbul, Koç Üniversitesi Yayınları.

Beck, Ulrich (2016) Risk Toplumu, Başka Bir Modernliğe Doğru (Çeviren: Kâzım Özdoğan; Bülent Doğan), 2. Baskı, İstanbul İthaki Yayınları.

Bulut, Nihat (2009) Sanayi Devriminden Küreselleşmeye Sosyal Haklar, İstanbul, On İki Levha Yayıncilık.

Committee on Economic, Social and Cultural Rights, "General Comment No. 14: The Right to the Highest Attainable Standard of Health (Art. 12)", 11 August 2000.

Davidai, Shai/Day, Martin V/Goya-Tocchetto, Daniela/Hauser, Oliver P./Jachimowicz, Jon M./ Usman, Mirza (2020) "COVID-19 Provides a Rare Opportunity to Create a Stronger, More Equitable Society".

De Campos, Thana Cristina (2017) "The Human Right to Health and Its Corresponding Responsibilities", In The Global Health Crisis: Ethical Responsibilities, Cambridge University Press. 
Dericiler Yücel, Özge (2014) Sosyal Haklar ve İnsan Hakları Hukuku Çerçevesinde Devletin Yükümlülükleri: Refah Devletinin Krizi Ekseninde Bir İnceleme, İstanbul, On İki Levha Yayıncılı.

Donnelly, Jack (1995) Teoride ve Uygulamada Evrensel İnsan Hakları (Çeviren: Mustafa Erdoğan; Levent Korkut), Ankara, Yetkin Yayınları.

Dworkin, Ronald M. (2011) "Siyasal Anayasanın Ahlaki Temelleri”, Anayasa Yargisı Dergisi, S: 28, s. 27-39.

Dworkin, Ronald M. (2007) Hakları Ciddiye Almak (Çeviren: Ahmet Ulvi Türkbağ) Ankara, Dost Kitabevi Yayınları.

Ertan, İzzet Mert (2015) Sosyal Hakların Uluslararası Korunması ve Avrupa Sosyal Şartı Sistemi, İstanbul, Beta Yayıncılık.

Ertan, İzzet Mert (2012) Uluslararası Boyutlarıyla Sağlık Hakkı, İstanbul, Legal Yayınevi.

European Committee of Social Rights, "Statement of Interpretation on the Right to Protection of Health in Times of Pandemic", 21 April 2020.

Freedman, Lynn P. (2005) "Achieving the MDGs: Health Systems as Core Social Institutions”, Development, p. 19-24.

Gevers, Sjef (2004) “The Right to Health Care”, European Journal of Health Law, Vol: 11, N: 1, Netherlands, p. 29-34

Goodman Timothy (2005) "Is There A Right to Health?", Journal of Medicine and Philosophy, Vol: 30, N: 6, p. 643-662.

Gözler, Kemal (2017) İnsan Hakları Hukuku, Bursa, Ekin Yayınları.

Gruskin, Sofia/ Tarantola, Daniel (2005) "Health and Human Rights", Perspectives on Health and Human Rights, (ed. Sofia Gruskin; Michael A. Grodin; George J. Annas; Stephen P. Marks), New York and London.

Güngören Bulgan, Birden (2020) Georg Jellinek'in Hak ve Devlet Kuramı, 2. Baskı, İstanbul, On İki Levha Yayıncılık.

Harris, D. J./O’Boyle, M./Bates, E. P./Buckley, C. M. (2013) Avrupa İnsan Hakları Sözleşmesi Hukuku (Çeviren: Ed. H. Dinçer), Avrupa Konseyi.

Harris, David John/Darcy, John (2001) The European Social Charter, (Harris ve Darcy), 2nd ed., N.Y., Transnational Publishers. 
Hayek, F. A. (2013) Law, Legislation and Liberty, London and New York, Routledge.

Hunt, Paul (2003) "Report of the Special Rapporteur," submitted in accordance with Commission resolution, 2002/31 E/CN.4/2003/58 13.

Hunt, Paul (2006) "The Human Right to the Highest Attainable Standard of Health: New Opportunities and Challenges", Transactions of the Royal Society of Tropical Medicine and Hygiene, Vol: 100, p. 603-607.

Hunt, Paul (2008) Report of the Special Rapporteur on "The Right of Everyone to The Enjoyment of The Highest Attainable Standard of Physical and Mental Health", General Assembly, UN Doc A/HRC/7/11.

Illich, Ivan (2017) Sağlığın Gaspı (Çeviren: Süha Sertabiboğlu), 4. Basım, İstanbul, Ayrıntı Yayınları.

Jani, Anant (2020) "Preparing for COVID-19's Aftermath: Simple Steps to Address Social Determinants of Health", Journal of the Royal Society of Medicine, Vol: 113, N: 6, s. 205-207.

Kapani, Münci (1993) Kamu Hürriyetleri, Ankara, Yetkin Yayınları.

Kılıç, Muharrem (2020) "Sağlıkta Şiddetin Önlenmesinin Mediko-Sosyal ve Yasal Dinamiği”, Rapor, Ankara, SETA Yayınları.

Kuçuradi, İonna (1999) Etik, Ankara, Türkiye Felsefe Kurumu Yayınları.

Kymlicka, Will (2020) Çokkültürlü Yurttaşlık (Çeviren: Abdullah Yılmaz), 3. Basım, İstanbul, Ayrıntı Yayınları.

Levins, Richard (2020) "Is Capitalism a Disease? The Crisis in U.S. Public Health", Brecht Forum in New York, Monthly Review, p. 8-33.

Locke, John (2012) Hoşgörü Üstüne Bir Mektup (Çeviren: Melih Yürüşen), 5. Baskı, Ankara, Liberte Yayınları.

Locke, John (2004) Yönetim Üzerine İkinci İnceleme (Çeviren: Fahri Bakırcı), Ankara, Babil Yayıncilık.

Mann, Jonathan M./Gostin, Lawrence/Gruskin, Sofia/Brennan, Troyen/Lazzarini, Zita/Fineberg, Harvey V. (1994) "Health and Human Rights”, Health and Human Rights, Vol: 1, N: 1, s. 6-23. 
Marks, Stephen P. (2013) "Emergence and Scope of the Right to Health", In Advancing the Human Right to Health, (ed. José M. Zuniga, Stephen P. Marks, and Lawrence O. Gostin), Oxford University Press, p. 1-38.

Nassif P., Luiza/Masterson, Thomas/Nikiforos, Michalis/Rios-avila, Fernando/Xavier, Laura (2020) "Pandemic of Inequality", Public Policy Brief Levy Economics Institute of Bard College No. 149, p. 1-16.

Oyal/Türkiye Davası, AİHM, 4864/05 Başvuru no, http://hudoc.echr.coe.int/eng?i=001-162088, s.e.t. 24.05.2020.

Porter, Dorothy (1999) Health, Civilization and the State: A History of Public Health From Ancient to Modern Times, London, New York.

Pras, Dainius (2015) "Report of the Special Rapporteur on The Right of Everyone to The Enjoyment of the Highest Attainable Standard of Physical and Mental Health", General Assembly, UN Doc A/HRC/29/33.

Rosanvallon, Pierre (2004) Refah Devletinin Krizi (Çeviren: Burcu Şahinli), Ankara, Dost Kitabevi Yayınları.

Ruger, Jennifer Prah (2005) "The Changing Role of The WORLD BANK In Global Health", American Journal of Public Health, Vol: 95, N: 1, p. 6070.

Stein, Felix/Sridhar, Devi (2017) "Health as a 'Global Public Good': Creating A Market For Pandemic Risk”, British Medical Journal (BMJ), Vol: 358, p. 1-4.

Şahin, Adil (2010) “Ulusalüstü İnsan Hakları Hukukunda Ekonomik Sosyal ve Kültürel Hakların Niteliği Bağlamında Sağlık Hakkının Kapsamı Üzerine Bir İnceleme”, Ankara Üniversitesi Hukuk Fakültesi Dergisi, C: 59, S: 4, s. 711-766.

Tarantola, Daniel (2008) "A Perspective on the History of Health and Human Rights: From the Cold War to the Gold War", Journal of Public Health Policy, Vol: 29, s. 42-53.

Thompson, Edward Palmer (2015) İngiliz İşçi Sınıfının Oluşumu (Çeviren: Uygur Kocabaşoğlu), 4. Baskı, İstanbul, Birikim Kitapları. 
Tichenor, Marlee/Sridhar, Devi (2017) "Universal Health Coverage, Health Systems Strengthening and the World Bank", British Medical Journal (BMJ), Vol: 358, p. 1-5.

United Nations- Department of Economic and Social Affairs, "Everyone Included: Social Impact of COVID-19",

https://www.un.org/development/desa/dspd/everyone-included-covid19.html, s.e.t. 19.06.2020.

United Nations (2020a) "Shared Responsibility, Global Solidarity: Responding to the Socio-economic Impacts of COVID-19".

United Nations (2020b) "COVID-19 and Human Rights-We Are All In This Together".

Uygun, Oktay (2019) Devlet Teorisi, 6. Baskı, İstanbul, On İki Levha Yayıncilik.

Uygun, Oktay (2013) “İnsan Hakları Kuramı”, Kamu Hukuku İncelemeleri, 2. Baskı, İstanbul, On İki Levha Yayıncılık.

Üzeltürk Tahmazoğlu, Sultan (2012) Anayasa Hukuku Açısından Sağlık Hakkı, İstanbul, Legal Yayınevi.

Wang, Zhicheng/Tang, Kun (2020) "Combating COVID-19: Health Equity Matters”, Nature Medicine, Vol: 26, p. 458-464.

WHO (1981) "Global Strategy for Health for All by the Year 2000”, Geneva.

WHO (2008) "Closing The Gap In A Generation Health Equity Through Action On The Social Determinants of Health", Geneva.

WHO (2020) "Basic Documents: forty-ninth edition (Including Amendments Adopted up to 31 May 2019)", Geneva.

World Bank (2020) "Protecting People And Economies: Integrated Policy Responses To Covid-19”, World Bank Group.

World Conference on Human Rights, "Vienna Declaration and Programme of Action", Vienna, 14-25 June 1993.

World Economic Situation And Prospects: Briefing No. 136 (2020) "COVID-19: Disrupting Lives, Economies and Societies". 
World Health Organization (WHO) (2005) International Health Regulations, Third Edition, Switzerland, WHO Press.

Yamin, Alicia Ely (2019) "Struggles for Human Rights in Health in an Age of Neoliberalism: From Civil Disobedience to Epistemic Disobedience”, Journal of Human Rights Practice, Vol: 11, p. 357-372.

Yamin, Alicia Ely (2017) "Taking the Right to Health Seriously: Implications for Health Systems, Courts, and Achieving Universal Health Coverage”, Human Rights Quarterly, Vol: 39, N: 2, p. 341-368.

\section{İnternet Kaynakları}

http://www.euro.who.int/en/about-us/organization/who-at-70/milestonesfor-health-over-70-years, s.e.t. 22.05.2020.

https://treaties.un.org/Pages/ViewDetails.aspx?src=IND\&mtdsg_no=IV$3 \&$ chapter $=4 \&$ clang=_en, s.e.t. 22.05 .2020 .

https://www.cdc.gov/coronavirus/2019-ncov/cases-updates/cases-in-us.html, s.e.t. 06.07 .2020 .

https://www.who.int/emergencies/diseases/novel-coronavirus-2019, s.e.t. 06.07.2020.

https://www.bbc.com/news/world-us-canada-52289056, s.e.t. 29.05.2020.

https://www.ohchr.org/EN/UDHR/Documents/UDHR_Translations/eng.pdf s.e.t. 22.05 .2020 .

https://apps.who.int/iris/bitstream/handle/10665/246107/9789241580496eng.pdf? sequence $=1$, s.e.t. 22.05 .2020 .

https://www.ohchr.org/Documents/HRBodies/CESCR/OProtocol_en.pdf s.e.t. 31.05 .2020 . 